Article

\title{
Ground Motion in Areas of Abandoned Mining: Application of the Intermittent SBAS (ISBAS) to the Northumberland and Durham Coalfield, UK
}

\author{
David Gee $^{1, *(1)}$, Luke Bateson ${ }^{2}$, Andrew Sowter $^{3}{ }^{(1)}$, Stephen Grebby $^{1}$ (D), \\ Alessandro Novellino $^{2}$, Francesca Cigna ${ }^{2,+}$ (D), Stuart Marsh ${ }^{1}$ (D), Carl Banton ${ }^{4}$ and Lee Wyatt ${ }^{4}$ \\ 1 Nottingham Geospatial Institute, University of Nottingham, Triumph Road, Nottingham NG7 2TU, UK; \\ stephen.grebby@nottingham.ac.uk (S.G.); stuart.marsh@nottingham.ac.uk (S.M.) \\ 2 British Geological Survey, Keyworth, Nottinghamshire NG12 5GG, UK; lbateson@bgs.ac.uk (L.B.); \\ alessn@bgs.ac.uk (A.N.); francesca.cigna@gmail.com (F.C.) \\ 3 Geomatic Ventures Limited, Nottingham Geospatial Building, Triumph Road, Nottingham NG7 2TU, UK; \\ andrew.sowter@geomaticventures.com \\ 4 Coal Authority, 200 Lichfield Lane, Mansfield, Nottinghamshire NG18 4RG, UK; \\ CarlBanton@coal.gov.uk (C.B.); LeeWyatt@coal.gov.uk (L.W.) \\ * Correspondence: david.gee@nottingham.ac.uk \\ † Present address: Italian Space Agency (ASI), Via del Politecnico snc, 00133 Rome, Italy.
}

Received: 20 June 2017; Accepted: 5 September 2017; Published: 13 September 2017

\begin{abstract}
In this paper, we investigate land motion and groundwater level change phenomena using differential interferometric synthetic aperture radar (DInSAR) over the Northumberland and Durham coalfield in the United Kingdom. The study re-visits earlier research that applied a persistent scatterers interferometry (PSI) technique to ERS (European Remote Sensing) and ENVISAT (Environmental Satellite) data. Here, the Intermittent Small Baseline Subset (ISBAS) DInSAR technique is applied to ERS, ENVISAT and Sentinel-1 SAR datasets covering the late 1990s, the 2000s and the mid-2010s, respectively, to increase spatial coverage, aid the geological interpretation and consider the latest Sentinel-1 data. The ERS data identify surface depressions in proximity to former collieries, while all three data sets ascertain broad areas are experiencing regional scale uplift, often occurring in previously mined areas. Uplift is attributed to increases in pore pressure in the overburden following the cessation of groundwater pumping after mine closure. Rising groundwater levels are found to correlate to ground motion measurements at selected monitoring sites, most notably in the surrounding area of Ashington. The area is divided by an impermeable EW fault; to the south, surface heave was identified as groundwater levels rose in the 1990s, whereas to the north, this phenomenon occurred two decades later in the 2010s. The data emphasize the complexity of the post-mining surface and subsurface environment and highlight the benefit that InSAR, utilizing the ISBAS technique, can provide in its characterization.
\end{abstract}

Keywords: ground motion; subsidence; coal mining; DInSAR; Intermittent SBAS

\section{Introduction}

High precision satellite radar interferometry is an effective and well established technique for monitoring earth surface motion [1]. It is a cost-effective method capable of surveying extensive areas to within millimetre precision regardless of weather and illumination conditions [2]. Differential interferometric synthetic aperture radar (DInSAR) utilizes stacks of high resolution synthetic aperture radar (SAR) data acquired over time from spaceborne platforms. DInSAR utilizes shifts in phase to measure changes in surface height in the satellite line-of-sight (LOS) direction and is capable of 
computing both average velocities (linear) and time-series (non-linear) to characterize ground motions occurring over the temporal epoch of image acquisitions [3].

A variety of persistent scatterer and small baseline interferometric techniques have been used to delineate and quantify coal mining related surface phenomena in Europe $[4,5]$ and farther afield $[6,7]$. However, it is common for temporal gaps to restrict multi-temporal DInSAR analysis in areas subject to historical or active mining [7]. Temporal gaps are common due to large deformation gradients often associated with mining subsidence [8,9] and decorrelation, the loss of coherence, which is common over coal mining areas [10].

Coherence, a by-product of the interferogram formation process, is a measure of phase correlation between two corresponding signals [11]. In areas of high coherence, targets are highly reflective and alter minimally over time. Conversely, in areas of low reflectance, where targets change over time (i.e., from year to year or from season to season), coherence is lost. In temperate, vegetated, rural settings the land surface can be variable due to both natural processes (e.g., soil shrink-swell) and human influences (e.g., agriculture) [12]. As a result, when differential interferograms are stacked, points for which coherence is maintained throughout the stack are generally abundant in urban locations, but sparse if not non-existent in rural areas. The optimum results produced by DInSAR are, therefore, obtained in urban or rocky areas, where coherence is recurrently high.

The Intermittent Small Baseline Subset (ISBAS) $[10,13]$ is an adapted version of the established low resolution SBAS [14] DInSAR time-series algorithm. It has been designed to improve the density and spatial distribution of survey points to return measurements in vegetated areas where DInSAR processing algorithms habitually struggle. The amendment of SBAS is introduced during unwrapping, after a set of low-resolution, two-pass, multi-looked interferograms with small perpendicular baselines have been produced. While SBAS unwraps targets where coherence is above a given threshold in all stacked interferograms, ISBAS considers targets where coherence is above a given threshold in a subset of the total number of interferograms within the stack. The algorithm can retrieve measurements for targets that are intermittently coherent throughout the period of observations. As a consequence, the density of survey points returned is higher and their distribution not limited to urban centres [15]. The ISBAS method has been successfully validated with ground truth over an area of gas production and geostorage in North Holland, the Netherlands [16]. The results demonstrated that the ISBAS technique can be used with confidence over locations where traditional ground-based survey measurements are not available.

Amongst many other applications, the ISBAS technique has previously been used for the monitoring of ground motion related to coal mining in the UK $[10,17,18]$. Sowter et al. (2013) [10] implemented the ISBAS technique on ENVISAT (Environmental Satellite) data covering the South Derbyshire and North West Leicestershire coalfields. The ISBAS-derived uplift, observed in agricultural and forested areas as well as urban centres, closely matched the outcrop of middle Coal Measures near Swadlincote, appearing bound by existing fault structures and spatially correlated to underground mining works abandoned in the early 1990s. Bateson et al. (2015) [18] applied ISBAS to ERS (European Remote Sensing) data acquired over the South Wales coalfield which has a complex history of surface movement due to coal mining and post-glacial stress relief [19]. Two discrete areas of uplift were observed in the proximity of the towns of Bargoed and Bedwas, again in mixed urban and rural land cover. In both investigations, the mechanism of uplift was not definitively confirmed but was thought to be related to increases in pore water pressure and/or the re-activation of existing faults.

Similar regional patterns of uplift following coalfield closures have been observed over other regions in the UK [20]. In Northumberland, a Persistent Scatterers Interferometry (PSI) analysis, an alternative DInSAR technique, was conducted on ERS and ENVISAT data covering the Northumberland and Durham coalfield and confirmed the changing patterns of ground motion over time $[21,22]$. Some correlations between the geology and PS derived ground motion products were made; however, in some cases the lack of PSI measurements in rural areas meant that the correlation between the motions and the geological and mining information was not clear. 
Accordingly, the principle aim of this paper is to better delineate ground motion on a regional scale in the Northumberland and Durham coalfield by applying the ISBAS technique to the ERS and ENVISAT data in order to extend coverage into areas of low coherence. This will subsequently enable a more comprehensive geological interpretation of the factors and processes associated with the observed ground motion. In addition, the launch of Sentinel-1 in April 2014 provides the opportunity to bring the study up to date by revealing more recent patterns of motion, therefore facilitating an investigation of ground deformation spanning three decades.

\section{Northumberland and Durham Case Study}

\subsection{Land Cover}

The area of interest (AOI) is located in the north east region of England and covers the counties of Northumberland, Tyne and Wear and County Durham (Figure 1). The AOI covers $2000 \mathrm{~km}^{2}, 40 \mathrm{~km}$ in width and $50 \mathrm{~km}$ in length. The north of the AOI extends up to the towns of Ashington and Morpeth and South to the towns of Houghton-le-Spring and Seaham. Agricultural land is most dominant within the AOI, with small pockets of forested and semi natural areas contained within these expanses. Notable urban regions exist along the north east coastline where the cities of Newcastle-upon-Tyne and Sunderland are situated on the banks of the River Tyne and River Wear respectively.
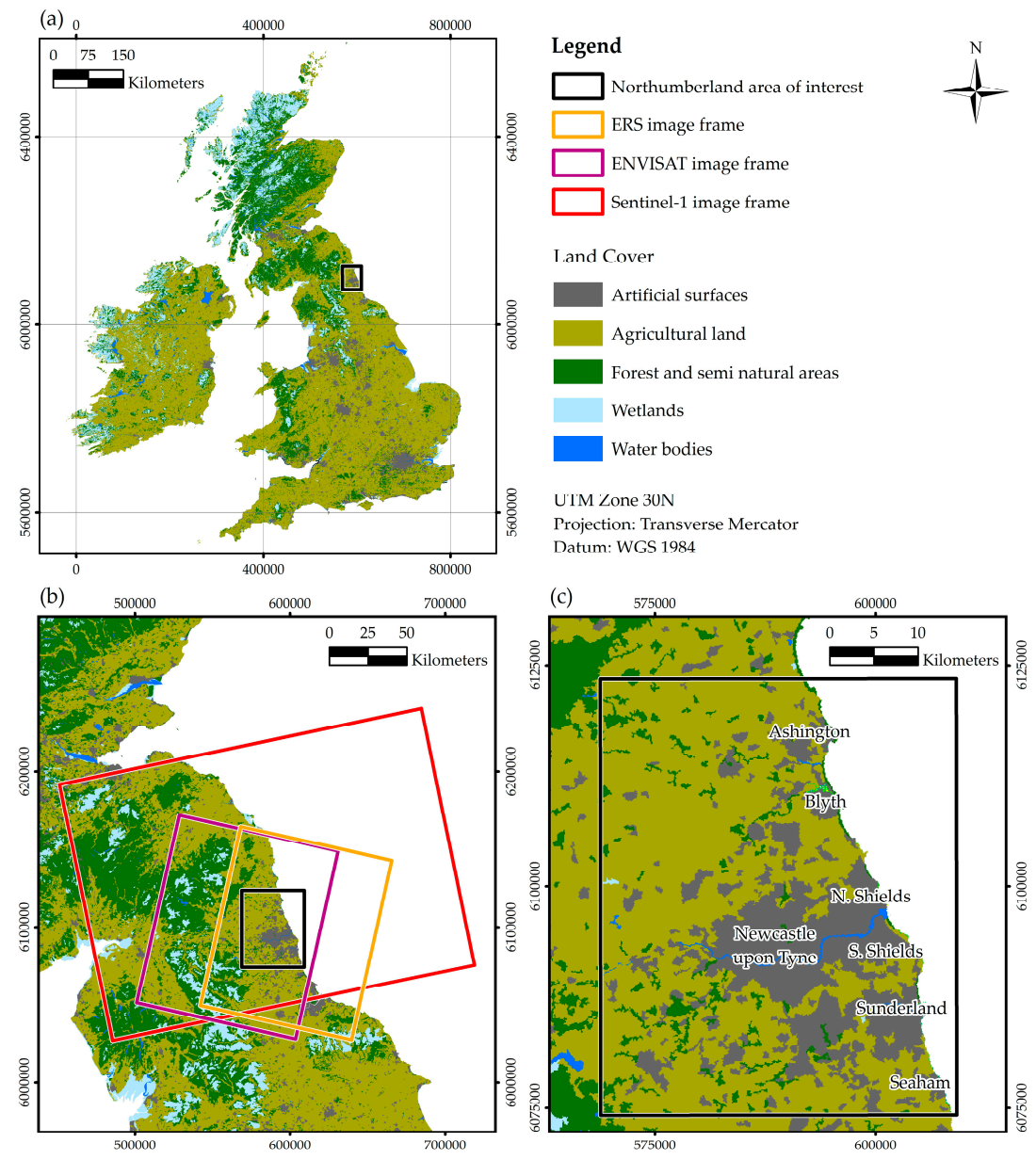

Figure 1. A land cover classification of the United Kingdom and Ireland taken from the 2012 CORINE (Co-ordinated Information on the Environment) Land Cover inventory [23]: (a) A map detailing the location of the Northumberland area of interest (AOI) within the United Kingdom; (b) Footprints of the ERS, ENVISAT and Sentinel-1 image frames; (c) The AOI with major towns and cities labelled. Copyright holder: European Environment Agency (EEA). 


\subsection{Geological Setting}

The geological sequence of interest includes bedrock of Carboniferous strata within the southern sector of the Northumberland Trough: the Yoredale Group (Stainmore and Alston Formation) and the Coal Measures Group (Figure 2). The Northumberland Trough is a major, asymmetrical SW-NE basin bounded to the south by the Stublick and Ninety Fathom faults and by the Cheviot Massif to the north [24]. The Carboniferous rocks dip gently eastwards and are overlaid unconformably by the Permian strata of the basal Yellow Sands Formation and overlying Magnesian limestone formations of the Zechstein Group [25]. The continuity of the outcrops of these units is interrupted by a number of normal faults. The edge of the Zechstein Group outcrop is typically marked by prominent scarp features overlooking the lower lying ground of the Coal Measures Group [22]. Superficial deposits of the Quaternary period, mainly resulting from the last glaciation and subsequent Holocene processes, are present throughout the area and intermittently blanket the bedrock with areas of the Zechstein Group limestone virtually free of cover deposits.
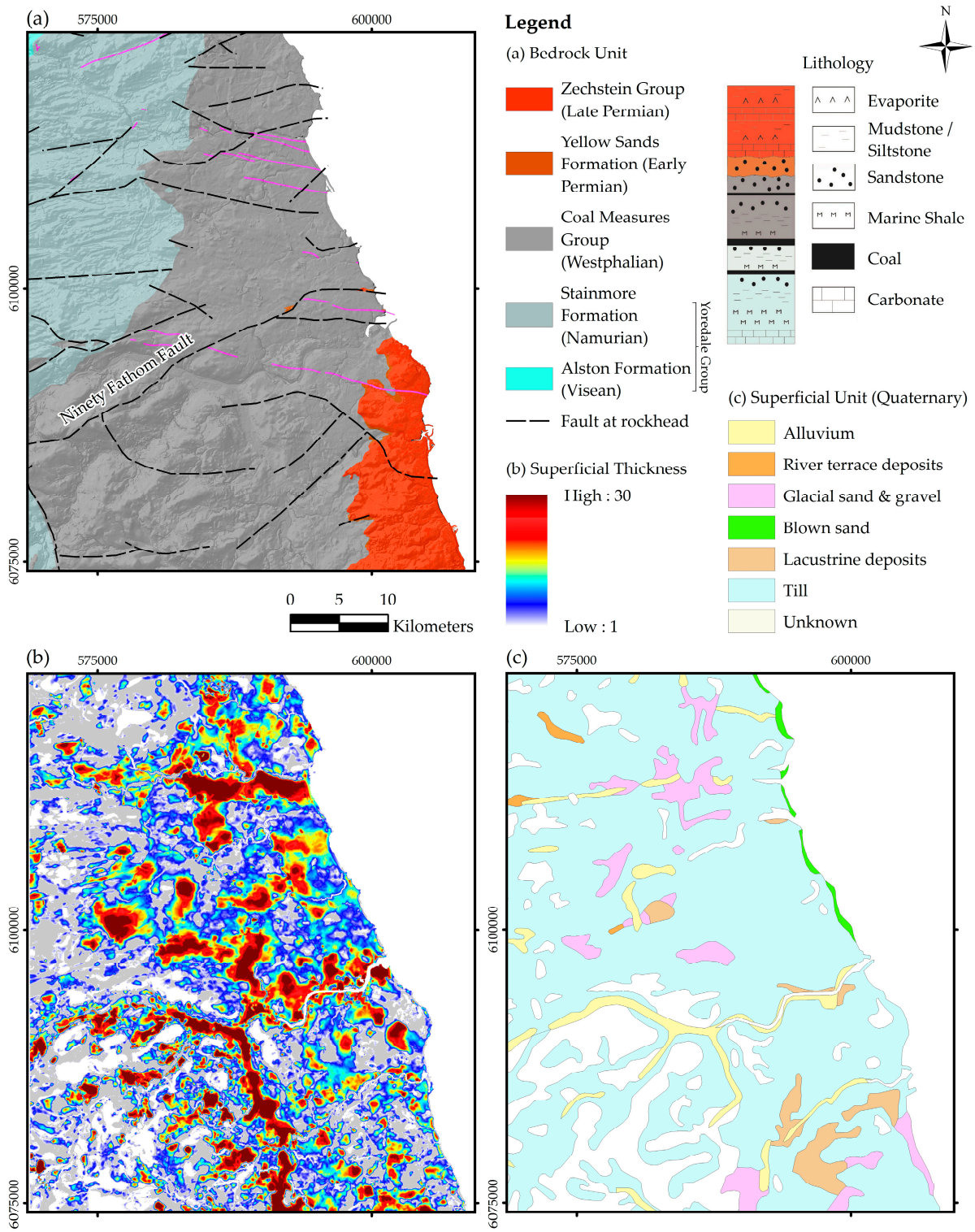

Figure 2. The geology of the AOI: (a) Bedrock geology overlain on topography; (b) Superficial thickness (interpolated from borehole data) [26]; (c) Superficial geology. 'Reproduced with the permission of the British Geological Survey @NERC. All rights Reserved'. 


\subsection{Northumberland and Durham Coalfield}

The Northumberland and Durham coalfield has a working history dating back to Roman times. Over twenty coal seams have been mined underground and the coalfield has been one of the major sources of opencast (surface-mined) coal in Great Britain. The coal-bearing strata dip gently to the east, with part of the coalfield concealed beneath the Permian strata to the south of the River Tyne. The geological structure of the area has governed the development of the coalfield with faults serving to divide the area into zones of "take". Early mining started in areas most accessible (i.e., inland in the west), where seams were often worked from the outcrop [27]. As mining and pumping methods developed, extraction from greater depths became viable; consequently, mining spread towards the eastern coast where deeper seams are situated, eventually advancing under the North Sea.

The coalfield has been extensively worked by both room and pillar and total extraction techniques. Longwall mining, where coal bearing rocks are machine worked from "longwall" faces at right angles from roadways running parallel to the face, is a method of total extraction and results in the immediate collapse of the roof and overlying rock into the void created behind. The displacement of rock can result in surface subsidence if the ratio of the width of extracted coal measures to the depth of the overburden exceeds a value between 0.1 and 0.5 , where the structure and strength of the overburden controls the precise ratio value. Room and pillar mining, where mined material is extracted across a horizontal plane creating horizontal arrays of pillars and rooms, results in between $15 \%$ and $90 \%$ of the material being extracted. Consequently, load on the pillars increases by up to $90 \%$ which can result in spalling, brittle failure or ductile failure. The potential for failure depends on the physical properties of the coal and the geometry of the mine; the collapse of multiple pillars can result in a surface depression, known as areal subsidence. The mechanical aspects of subsidence produced from longwall mining methods are generally better understood compared with room and pillar mining [28].

\section{SAR Processing}

\subsection{ERS and ENVISAT}

Archive ERS and ENVISAT C-band ( $5.6 \mathrm{~cm}$ wavelength-5.3 GHz frequency) Stripmap SAR products were obtained and processed separately. The Single Look Complex (SLC) image stacks are acquired in the radar line-of-sight (LOS), the incidence angle ranges between $20.1^{\circ}$ and $25.9^{\circ}$ from near to far range with respect to the surface normal. Twenty-five ERS descending images spanning nearly a five year period from 24 May 1995 to 30 December 1999 (Appendix A) and twenty-one ENVISAT descending images spanning approximately a six year period from 3 December 2002 to 7 October 2008 (Appendix B) were identified for processing as they imaged the AOI with greatest frequency. The complete image frames were processed on both occasions which covers an area of approximately $100 \mathrm{~km} \times 100 \mathrm{~km}$, at a ground spatial resolution of $25 \mathrm{~m}$ in range and $5 \mathrm{~m}$ in azimuth [29].

The ERS stack was co-registered with respect to the master acquired on 20 November 1997, while the ENVISAT stack was co-registered to the scene acquired on 11 January 2005. Interferograms were generated with restrictions of 4 years on the temporal baseline and $250 \mathrm{~m}$ on the perpendicular orbital baseline. These restrictions are common to small baseline surveys using ERS and ENVISAT data, minimizing both temporal and spatial decorrelation in the interferograms and enhancing the quality of phase. Multilooking, applied to reduce noise and increase coherence, was implemented by a factor of 4 in range and 20 in azimuth to produce pixels of approximately $100 \mathrm{~m} \times 100 \mathrm{~m}$. Pixels deemed coherent within each interferogram displayed a coherence $\geq 0.25$.

An ISBAS analysis improves ground coverage by utilizing targets that are not high quality in every interferogram. As detailed by Sowter et al. (2013) [10], the algorithm accepts pixels, termed coherent pixels, which meet a minimum quality standard. Those retained in the analysis displayed a coherence $\geq 0.25$ in a minimum number of $(m)$ interferograms, when $(m) \leq$ to the total number of interferograms $(N)$. By unwrapping each interferogram individually the technique accepts intermittently coherent targets throughout the stack. The choice of interferogram threshold $(m)$ is a 
trade-off between coverage and quality, the value of which has a direct correlation with the standard error of the derived velocities [30].

The ERS analysis produced 102 multi-looked differential interferograms where an interferogram threshold $(\mathrm{m})$ of 30 was determined. The temporal and orbital baselines of image pairs are plotted relative to the master in Figure 3a. All velocities are computed with respect to a reference point, it is important that this location is both stable and coherent in every interferogram. A reference point in North Shields $\left(55.00^{\circ} \mathrm{N},-1.46^{\circ} \mathrm{E}\right)$ was chosen based upon the data from the British Geological Survey (BGS) GeoSure natural geohazard datasets and its urban location. The control point is in an area of low susceptibility to geohazards and is surrounded by coherent targets which helps to minimize the propagation of errors during phase unwrapping.

(a)

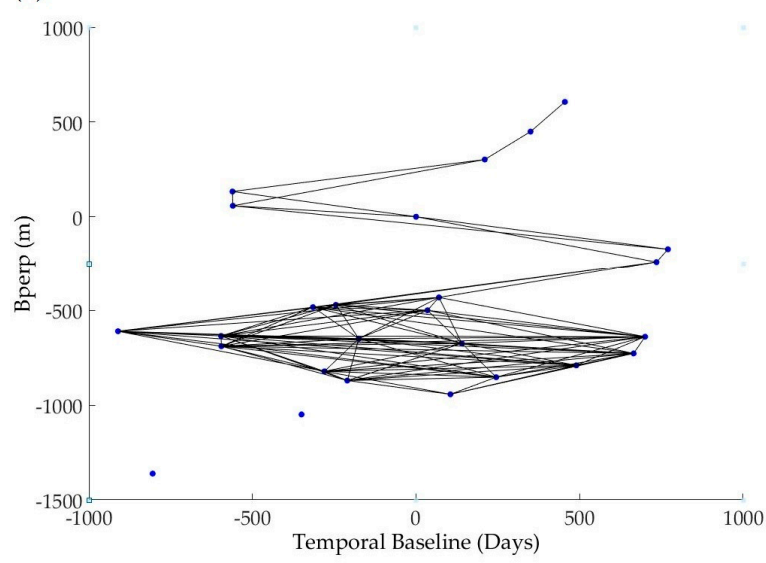

(b)

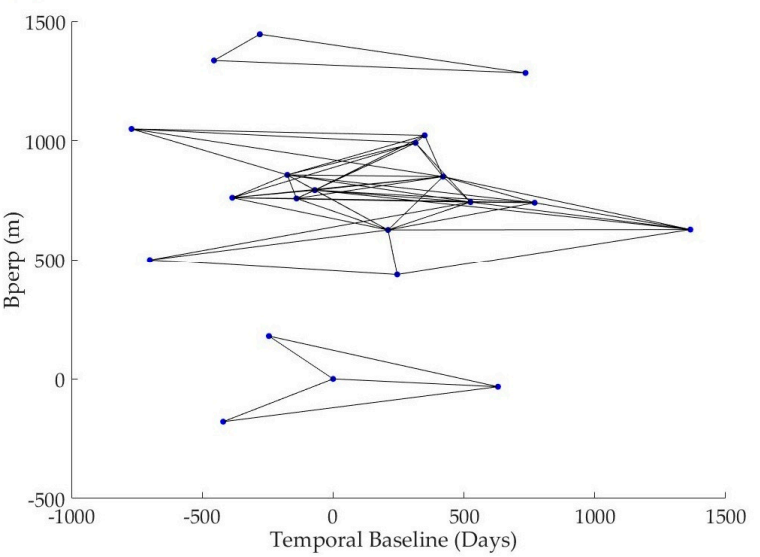

Figure 3. Temporal and perpendicular baselines of image pairs relative to the master. Image acquisitions are represented by points and differential interferograms, satisfying the orbital and temporal requirements, by lines: (a) ERS Synthetic Aperture Radar (SAR) (master: 20 November 1997);

(b) ENVISAT Advanced Synthetic Aperture Radar (ASAR) (master: 11 January 2005).

The ENVISAT analysis produced 60 multi-looked differential interferograms (Figure 3b), from which an interferogram threshold $(m)$ of 15 was applied. The reference point was, correspondingly to the ERS analysis, situated in North Shields for the aforementioned reasons.

Topographic phase was removed using a 90 m Shuttle Radar Topography Mission (SRTM) Digital Elevation Model (DEM) [31] and coherent and intermittently coherent pixels within each differential interferogram were unwrapped using a statistical-cost network-flow algorithm [32]. Following the method proposed by Berardino et al. (2002) [14] both linear and non-linear models of deformation were applied to compute average rates of motion and time-series per pixel. Additionally, the standard error for each pixel is computed via a least squares covariance analysis which expresses the goodness-of-fit between the interferogram values and derived linear velocity. Finally, due to the different incidence angles of ERS/ENVISAT (20.1-25.9 $)$ and Sentinel-1 (29.1-46 $)$, LOS velocities were converted into vertical velocities by means of dividing by the cosine of the incidence angle for each pixel.

\subsection{Sentinel-1}

Thirty-six Sentinel-1 Interferometric Wide Swath SLC images were identified as most suitable for analysis over the AOI (Appendix C). Radar LOS varies from $29.1^{\circ}$ to $46.0^{\circ}$ across the swath from near to far range, with a single look resolution of $5 \mathrm{~m}$ in range and $20 \mathrm{~m}$ in azimuth [33]. The full Sentinel-1 scenes are $250 \mathrm{~km}$ in width, in this case much of which is located over North Sea. A subset of the image was processed, approximately $90 \mathrm{~km} \times 90 \mathrm{~km}$, contained within IWS1 and IWS2.

The nominal repeat cycle of the Sentinel-1 imagery used is 12 days, less than the 35 day repeat cycles of the ERS and ENVISAT satellites. In the period of approximately 12 months, Sentinel-1 
acquired more SLC images of the AOI than ENVISAT in its total operational lifetime. This is of great benefit to a DInSAR analysis as more observations generally implies a lower standard deviation of error, as demonstrated for the area of Doncaster in the UK by Novellino et al. (2017) [34]. The C-band (5.555 cm wavelength-5.405 GHz frequency) level-1 images processed were acquired on an ascending geometry; a stack of descending Sentinel-1 imagery were also considered to try and maintain uniformity with the geometries of the ERS and ENVISAT data, however only 26 images covered the full AOI and therefore generated a less reliable result. The ISBAS processing of the Sentinel-1 data followed the approach defined in Sowter et al. (2016) [15].

Coregistration was performed with respect to a master image acquired on 25 January 2016. Multilooking was implemented by a factor of 22 in range and 5 in azimuth which increased pixel size to approximately $90 \mathrm{~m}$ in ground range. A dense network of 520 differential interferograms were generated, with restrictions of $250 \mathrm{~m}$ on the perpendicular orbital baseline and one year on the temporal baseline, plotted in Figure 4. Comparing against the networks produced from the ERS and ENVISAT analysis (Figure 3) the improved accuracy of Sentinel-1 orbits is evident, designed to operate within a narrow orbital tube radius of $50 \mathrm{~m}$ for the majority of its operational lifetime [35]. Consequently, in concurrence with the reduced revisit time and increased number of acquisitions, there is far more redundancy in the network.

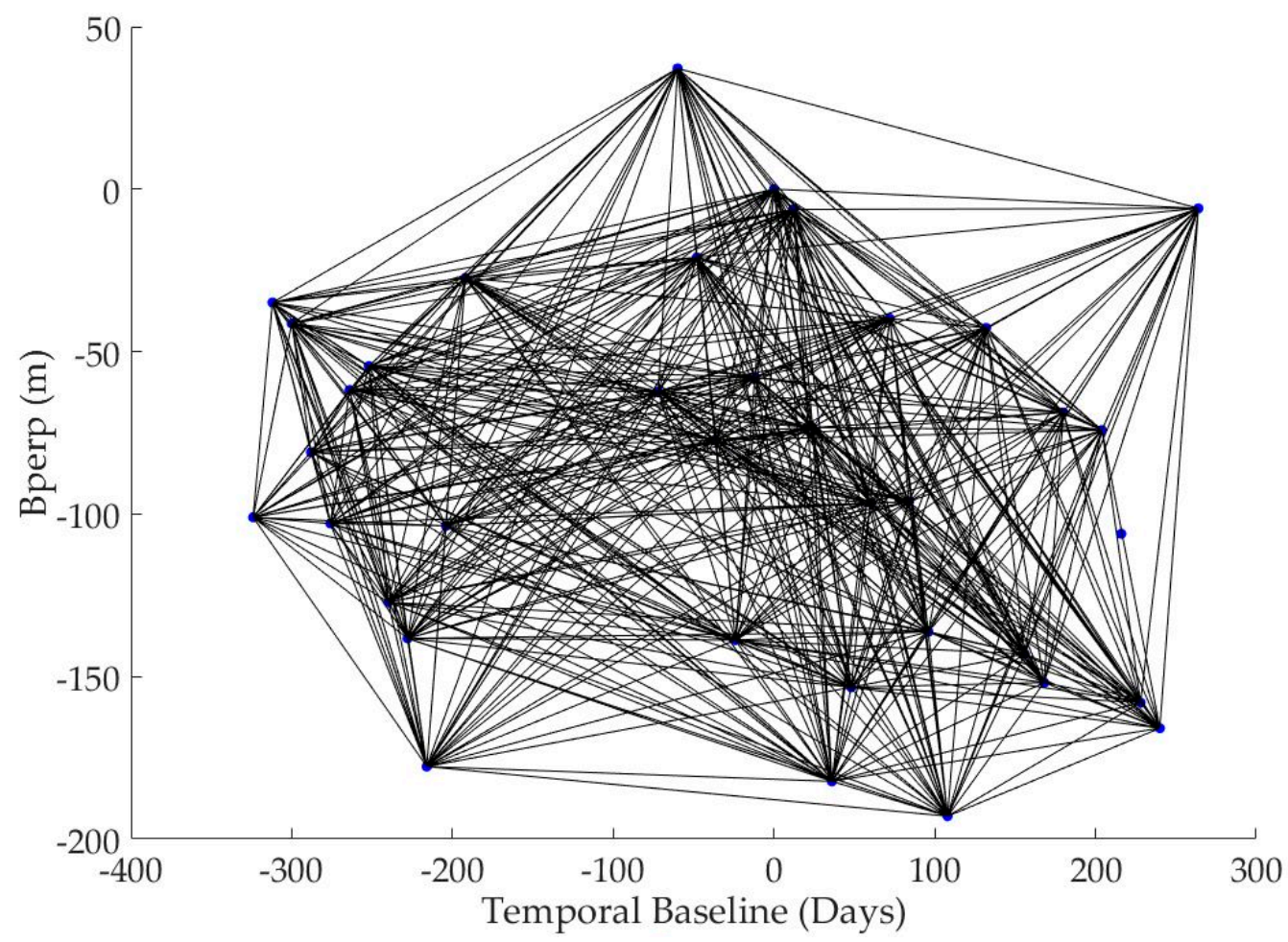

Figure 4. Sentinel-1 Synthetic Aperture Radar (SAR) temporal and perpendicular baselines of image pairs relative to the master acquired on 25 January 2016.

An interferogram threshold of 135 was selected and, following the same approach as for the ERS and ENVISAT processing, the reference point was located in North Shields $\left(55.00^{\circ} \mathrm{N},-1.46^{\circ} \mathrm{E}\right)$, topographic phase was removed using a STRM DEM and SAR orbital parameters, coherent and intermittently coherent pixels were unwrapped to derive linear velocities, standard errors and time-series per pixel which were subsequently projected into the vertical direction. 


\section{Ground Motion in North East England}

\subsection{ISBAS Processing Coverage}

The analysis covered $99 \%, 89 \%$ and $95 \%$ of the land surface area of the full extents processed in the cases of ERS, ENVISAT and Sentinel-1 respectively, providing a broad and complete distribution of velocities over all land cover types (Figure 5). Had velocities been derived for targets where coherence is recurrent in every interferogram, coverage would have only been $7 \%, 2 \%$ and $12 \%$ for the respective data sets. Dense coverage was achieved not only in areas of high coherence, but over agricultural land and woodland areas. Standard errors are lowest in urban areas due to increased coherence and consequently more coherent interferograms to derive linear velocities.

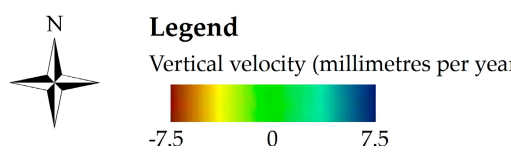

(a) 575000
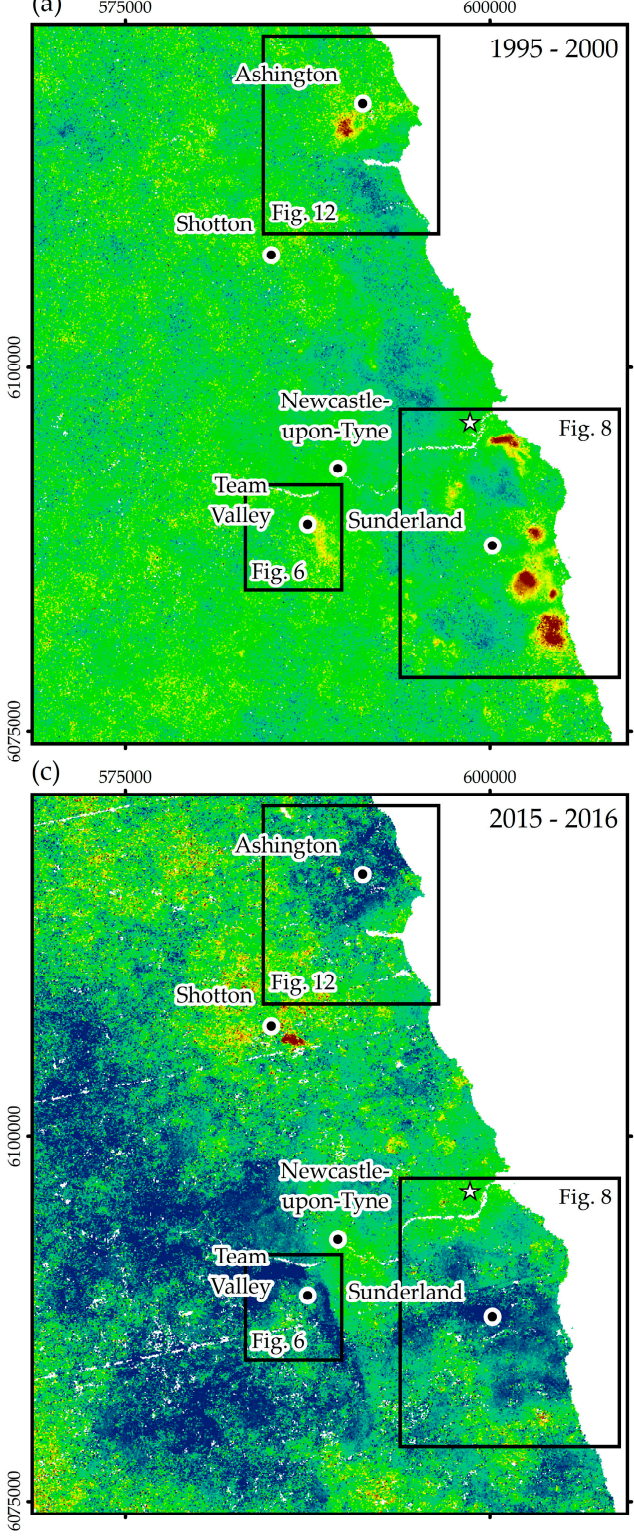

is Reference point Coal seam contour

(b) 575000

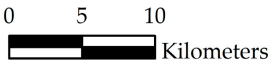

600000
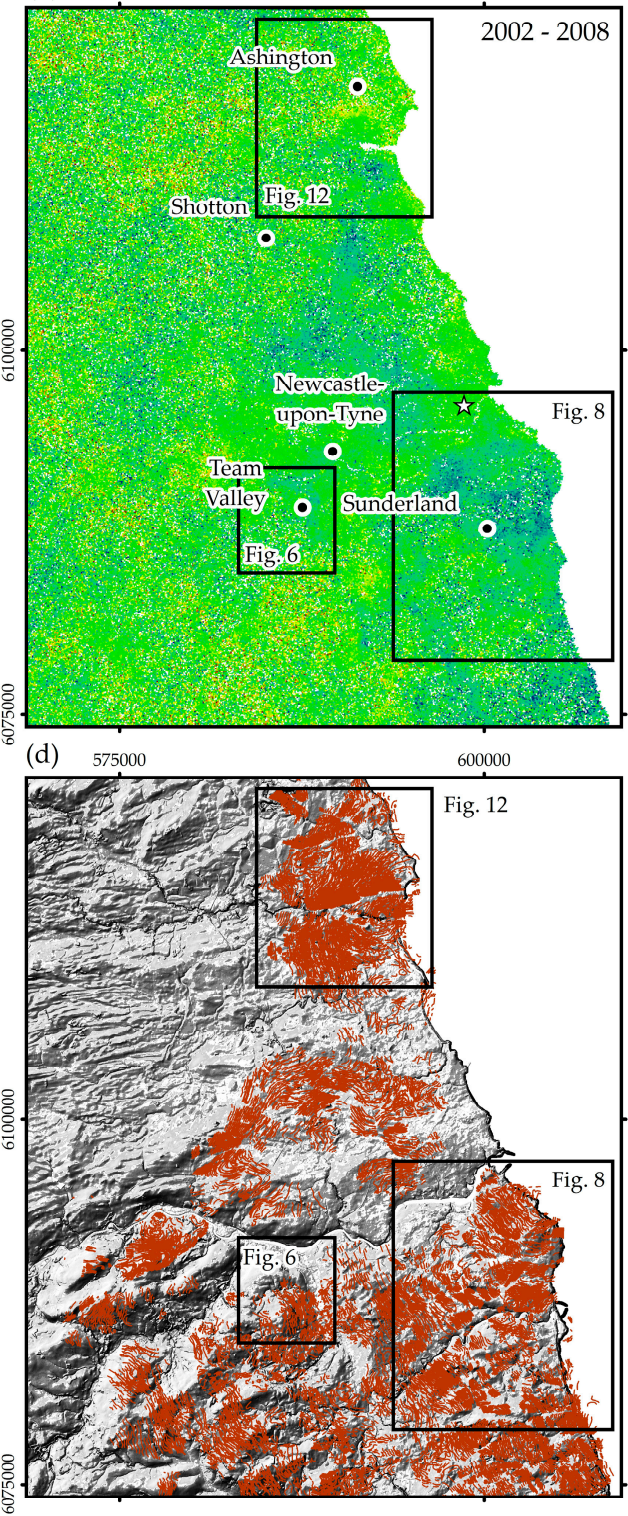

Figure 5. ISBAS average vertical velocities (millimetres per year): (a) ERS (b) ENVISAT (c) Sentinel-1 (d) Coal seam contours and topography. 


\subsection{Linear Velocities}

Several notable areas of localised subsidence were identified along the coastline in the ERS analysis, while uplift occurred in the northern half of the AOI and approximately $5 \mathrm{~km}$ inland in the south (Figure 5). Uplift occurs over larger regional areas, while subsidence is localised and of a greater magnitude. There has been a significant change in the spatial patterns of motion between the ERS and ENVISAT data sets; areas of localised subsidence present in the ERS data have stabilised and uplift in the north has reduced in velocity. The results achieved in the ERS and ENVISAT analysis compare well to results produced by FugroNPA using PSI [21]. These were supplied for the Terrafirma Product Interpretation Report: Northumberland (ESRIN/Contract No. 4000101274/10/I-AM) [22] commissioned by the Coal Authority and confirm the findings of a distinct change in velocities between data sets. The Sentinel-1 analysis shows that the trend of regional uplift has strengthened. Uplift occurring around Sunderland during the ENVISAT epoch has increased in velocity, while a large regional pattern of uplift has developed inland in the western half of the AOI.

Table 1 summarizes the statistics of the linear velocities and standard errors. It might be expected, since there are approximately 50\% more Sentinel-1 acquisitions than ERS/ENVISAT, that standard errors are lowest for Sentinel-1, which is not the case. However, data acquired over shorter epochs reduces the ability to accurately retrieve the underlying deformation signal. The relatively short time period of the Sentinel-1 analysis ( $\approx 18$ months) is reflected in the amount of noise present in the linear velocities and the standard errors. Atmospheric signal, a prevailing InSAR error source, can be accurately removed via the stacking of numerous acquisitions to retrieve the underlying deformation based upon the assumption that atmospheric delay is random over time. The stratified troposphere is characterized by temporal variations, principally due to precipitation. Interferometric signals, therefore, have a seasonal component which can be aliased by the temporal sampling of SAR acquisitions [36,37]. Furthermore, the TOPS configuration of Sentinel-1 products generates additional difficulties, with respect to stripmap products, and requires a greater amount of acquisitions to accurately sample the atmosphere since constitutive bursts are imaged through different section of the atmosphere [33].

Table 1. A comparison of the statistics of ERS, ENVISAT and Sentinel-1 ISBAS analyses over the Northumberland AOI.

\begin{tabular}{cccc}
\hline Statistic & ERS SAR & ENVISAT ASAR & Sentinel-1 SAR \\
\hline & Velocity (Millmetres/Year) & \\
\hline Mean & 0.9 & 0.7 & 3.5 \\
Minimum & -14.0 & -14.5 & -16.0 \\
Maximum & 10.6 & 14.6 & 19.0 \\
Standard Deviation & 1.9 & 2.5 & 3.4 \\
\hline & Standard Error (Millimetres) & \\
\hline Mean & 1.6 & 2.4 & 0.8 \\
Minimum & 0.5 & 0.6 & 4.9 \\
Maximum & 4.0 & 8.0 & 0.7 \\
Standard Deviation & 0.4 & 0.8 & \\
\hline
\end{tabular}

\section{Discussion}

As mentioned above, the ground motion results reveal large regional extents of uplift with localized hotspots of subsidence. The following section discusses the link between the observed patterns of ground motion and the geology, history of coal mining and the hydrogeology of the Northumberland region. 


\subsection{Relationships between Ground Motion and Geology}

\subsubsection{Bedrock Geology}

A number of potential relationships between the velocities and the geology are apparent. However, on the whole, there appears to be no correlation between any of the ERS, ENVISAT or Sentinel-1 velocities and the bedrock geology, with no evidence to indicate that specific geological units are responsible for the observed surface motion.

\subsubsection{Superficial Deposits}

In general, there is little correlation between any ground motion and the distribution or thickness of superficial deposits, particularly compressible deposits and those with potential for shrink-swell. The exception, however, is in the area of Team Valley, where the land surface changes from subsidence to stability to uplift over the course of the ERS, ENVISAT and Sentinel-1 analyses (Figure 6). Team Valley is a deep buried valley which characterizes the pre-glacial channel of the River Wear. The valley extends downward through Coal Measures to $-46 \mathrm{~m}$ above ordnance datum and is infilled with an interlensing complex of glacial clays, laminated-clays, silts and sands, overlain by alluvium [38]. Subsidence identified in the ERS data is situated within the deepest parts of the channel, while the glacial till at the margins are stable. Subsidence could be attributed to progressive compaction as the area coincides with an extensive area of industrial development in the Team Valley and Gateshead Metro Centre. Large areas are covered with artificial surfaces sealing the subsurface from rainfall recharge; it is plausible that de-watering of Quarternary sediments in combination with loading, albeit from comparatively light-weight structures, could be significant in creating subsidence.

The ENVISAT data reveals that areas experiencing subsidence in the 1990s, have stabilized, with a small degree of uplift identified further north in the valley. Sentinel-1 velocities indicate this trend has strengthened with strong uplift in the Team Valley. The pumping of mine water within Team Valley could have significant effects on the land surface as a known programme of ground water control is present in this part of the former coalfield.

\subsubsection{Geological Structure}

When comparing derived velocities to the geological structure, a number of cases emerge for which patterns of motion appear to be associated with major geological faults (Figures 7 and 8 ). In such cases there is no indication that the faults are directly responsible for the motion, but influence motion by accommodating or constraining it. The constraining of motion appears to be related to both regional patterns of uplift, as well as localised subsidence. Examples of such a relationship in the surrounding areas of Sunderland and Ashington are discussed in more detail in Section 5.4.

\subsection{Relationships between Ground Motion and Coal Mining}

Subsidence is an inevitable consequence of mining activity [28]. It has been approximated that 4800 million tonnes of coal has been extracted from UK mines, consequently leaving 1000 million cubic metres of voids [39]. Five mines in the AOI were active at some point during the study period; four opencast and one deep mine, Ellington. Ellington was closed in 2005 [40] but there is no spatially correlated subsidence associated with this mine as would be expected since the workings are located under the North Sea (Figure 5). One localized hotspot of deformation is revealed in the Sentinel-1 analysis, corresponding to Shotton opencast coal mine, which was operational throughout the period of Sentinel-1 SAR acquisitions (Figure 5c). A number of potential relationships between ground motion and coal mining were examined including: mine entries; coal seam contours and underground workings.

Within the AOI there are a total 7811 mines entries, the majority of which exist in the Pennine Middle Coal Measures Formation with far fewer located in the Zechstein Formation where Coal Measures are deepest (Figure 2). Areas of subsidence present in the ERS analysis are in proximity 
to entries to former collieries, for example at Westoe, Wearmouth, Ryhope in the Sunderland area (Figure 8). However, it is challenging to make correlations with this data since there are many mine entries within the AOI where subsidence is not present.
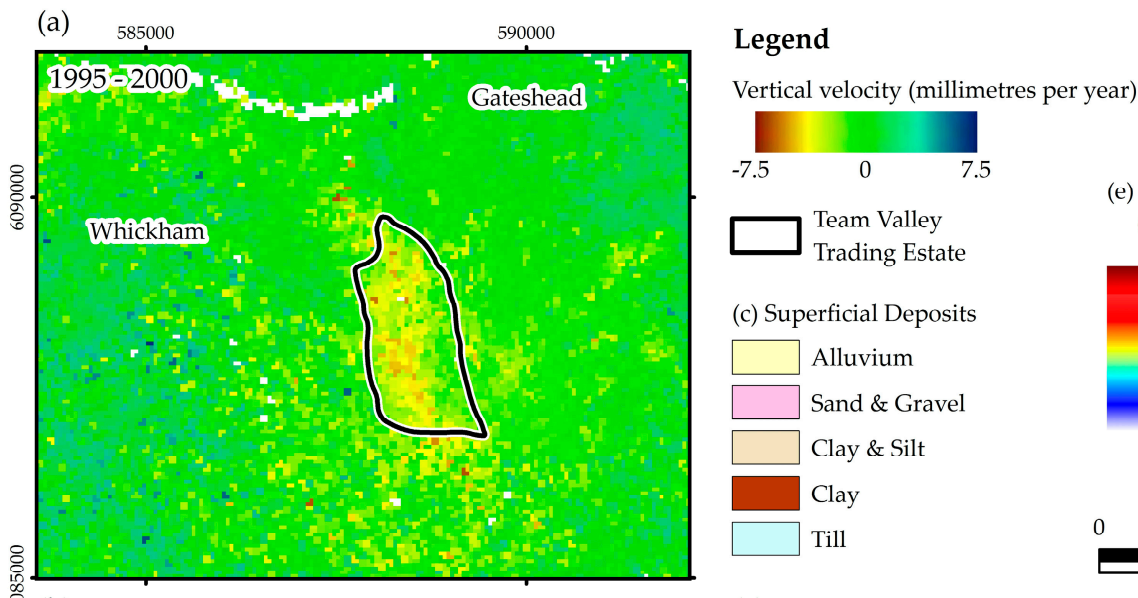

(c) Superficial Deposits

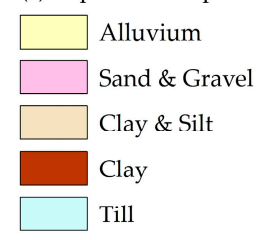

(c) 585000
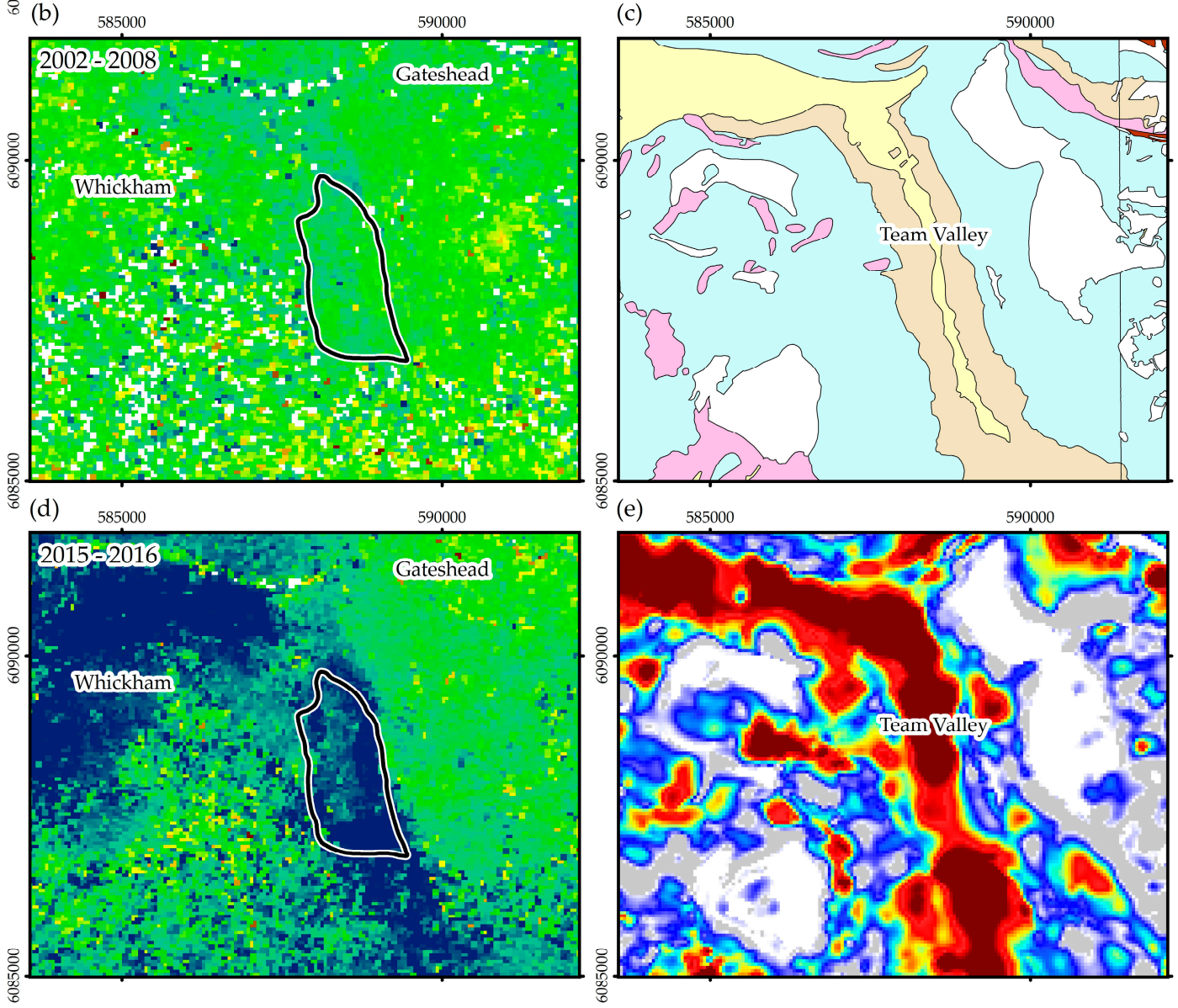

Figure 6. (a) ERS ISBAS vertical velocities (millimetres per year); (b) ENVISAT ISBAS vertical velocities (millimetres per year); (c) Superficial geology; (d) Sentinel-1 ISBAS vertical velocities (millimetres per year); (e) Superficial thickness. 'Reproduced with the permission of the British Geological Survey CNERC. All rights Reserved'. 
There is a relationship between areas of motion and seam contours at many locations in all three data sets (Figure 5). As faults often delimit Coal Measures it is perceptible that areas of motion are delimited by these boundaries. An example of such a relationship occurs in the surrounding area of Ashington, with evidence to suggest uplift has been caused by former mining activities (Figure $5 c, d$ ). The majority of mining and resultant ground motion would have been completed long before the satellite data was acquired, therefore subsidence associated with surface hazards or pillar collapse are localized. No relationships were observed when analysing any ground motion in conjunction with coal seams categorised by depth or working dates.

There is no distinct relationship between underground workings and ground motion in any of the SAR observations. Nonetheless, establishing relationships with these data is challenging because the majority of Coal Measures in the AOI have been worked extensively, at multiple depths by both pillar and stall and total extraction techniques. Coal mine abandonment plans were not a requisite in the United Kingdom until 1859, hence not all mining has been documented. Additionally, old mine plans are often inaccurate due to poor surveying techniques and pillar robbing [41].

\subsection{Relationships between Ground Motion and Ground Water Levels}

Groundwater rebound is the reasoned cause of regional-scale surface uplift [42,43]. Surface heave phenomena has previously been identified by geodetic levelling [44-46] and radar interferometry $[10,13,17,18,20-22,47-51]$ above a number of abandoned coalfields in different geographies. Deep underground coal extraction requires the pumping of groundwater to maintain safe working conditions within the mine [52]. Systematic pumping ordinarily ceases following the abandonment of underground coal mines and groundwater levels begin to rebound. Monitoring by the Coal Authority in the Durham Coalfield clearly identifies mine water recovery, although part of the coalfield is still controlled by pumping. As the rock matrix reverts back to previously saturated conditions, pore water pressure increases and consequently the rock expands which can produce an expression at the surface [43]. Surface elevation is thought to only represent several percent of any previously identified subsidence during active mining and to occur gradually over a larger area than previous subsidence basins [53].

Broadly, coalfields can become associated with a number of stability and contamination issues following abandonment, due to prominent changes in topography and hydrogeological regime [54]. The rise of mine water and flooding of abandoned workings can have some detrimental consequences including: residual subsidence; the reactivation of existing faults; mine gas migration; slope instability; and influence the geotechnical properties of the ground [55]. Individual coalfields may be subject to some or none of the identified issues. Subsidence and slope instability have not been associated with mine water recovery in British coalfields.

Historical indications demonstrate that there remains a risk of ground instability long after pillar and stall and longwall workings have been abandoned. The delayed onset of motion can be initiated by a number of factors including creep of the overburden, pillar deterioration, collapse of the roof and failure of the floor as a result of seatearth softening. There is potentially no time limit for pillar and stall instability. Furthermore, deeper mine activity can trigger events in shallower, often unrecorded, mines [28]. The risk of surface instability is substantially higher during the transitory phase of groundwater rise, due to the redistribution of stress within the rock matrix. Risk is reduced once a new hydraulic and hydrogeological equilibrium is reached, following saturation to historical levels [53]. In most cases in the UK, the pre mining hydrogeology is not known but it is assumed rebound is to the pre-mining levels. 


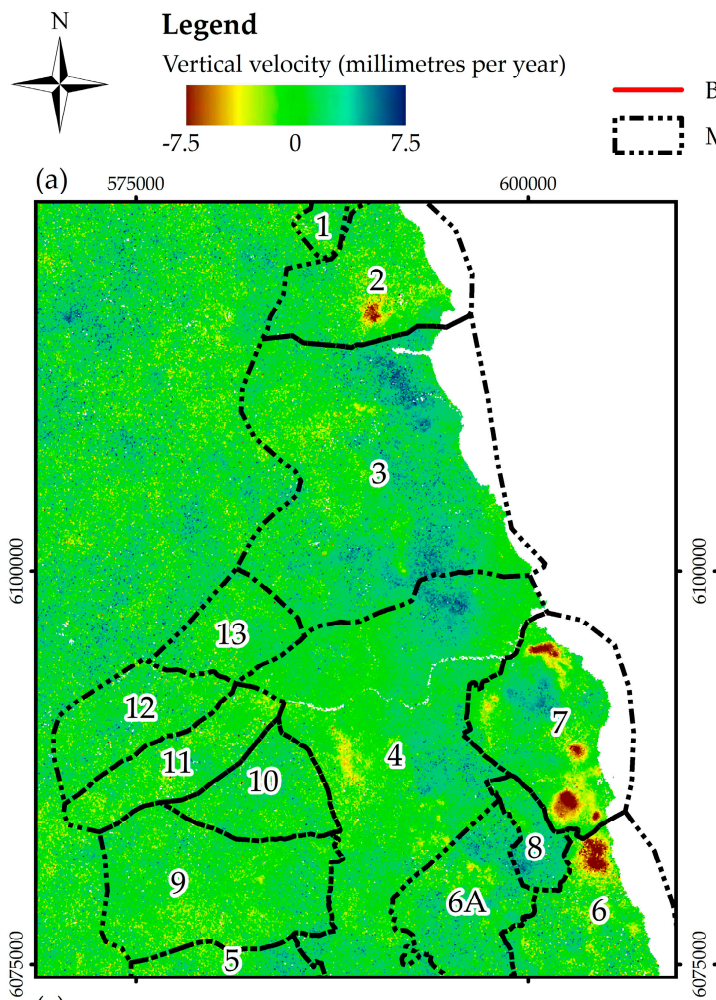

Base coal measure fault

Mine water pond

Kilometers
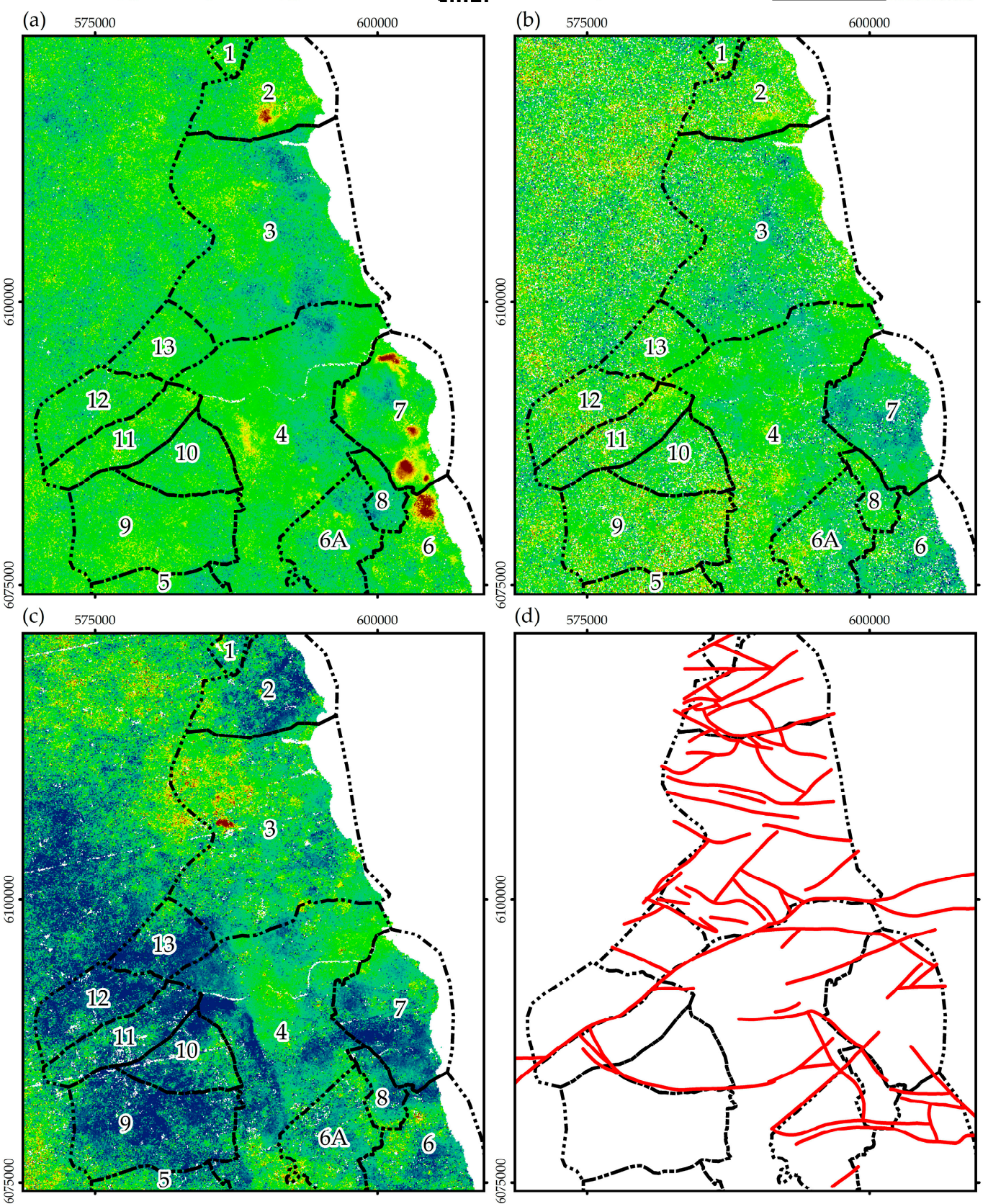

Figure 7. ISBAS vertical velocities (millimetres per year) with minewater ponds overlaid: (a) ERS (b) ENVISAT (c) Sentinel-1; (d) Minewater ponds and base coal measure faults. 
Rising groundwater creates a complex subsurface environment. Water ingress into former workings does provide some support pressure inside the mined voids. Ingress is aided by the disturbance, fracturing and disintegration of roof layers and overlying rock mass during mine operation, consequently permeability and porosity are increased [44,53]. However, Coal Measures rocks can lose significant strength on water saturation as a result of mineralogical changes to the clays within the rock matrix, stress corrosion or water absorption [56] and has been associated with pillar failure in within former mine workings [57,58]. Additionally, the chance of failure can increase as the saturation of soil within the overburden increases vertical stress on the strata [44].

Fault reactivation is a further consequence of rising minewater [59]. The incidence of fluids within fault zones have been shown to induce seismicity $[60,61]$. An increase in fluid pore pressure reduces fault plane shear strength. Reactivation can occur if the reduction in shear strength counterpoises the normal stress acting across the fault [62]. Since Coal Measures sandstones in the Durham coalfield possess very little intergranular permeability, groundwater movement is principally through fractures in the sandstone [63]. Mining has extensively disrupted and complicated the hydrogeology and increased permeability. Rising groundwater levels have previously been associated with incidences of fault reactivation in the Durham Coalfield [64].

In the area of study, rather than abruptly turn off all pumps in the abandoned coalfield, the Coal Authority have continued to pump minewater from a number of sites as part of a strategy to control the rise of water levels. Since mining was operational there has been a reduction in the number of operational pumping sites and, consequently, groundwater levels in some eastern parts of the coalfield have recovered to levels close to the base of the Permian rocks. However, in more recent years $(\approx 10$ years) the number of operational sites may have increased; active management of groundwater is important so to prevent potential contamination of important aquifers within these rocks. For example, it is known that approximately $4 \mathrm{~km}$ south of the study area that groundwater pumping began at a new facility at the former Horden Colliery in July 2004 [65].

Newcastle University, the Environment Agency and Coal Authority have conducted previous work over the AOI to better understand the hydrogeological regime and the effects of altering pumping regimes following mine closure [21,22,66-70]. Modelling studies have previously attempted to predict minewater rebound. The coalfield is divided into "ponds", considered single hydraulic units which homogenously rise or fall principally depending on ground water pumping. Some of these ponds are connected (hydraulically) to other ponds, whilst some are not. Some of the connections between ponds are unclear and can change over time. The connections can be at different depths, hence some ponds can become joined or isolated with groundwater level changes. From the information made available, the location of these ponds appears to be controlled in many cases by the geological structure, specifically by geological faults (Figure 7). The ponds, which cover a greater area than the AOI, are thought to refill in increasing numerical order defined in Figure 7.

The filling of ponds in numerical order is largely supported by the Sentinel-1 data (Figure 7c). The rates of uplift have increased over time in ponds $4-13$. Pond " 2 " does not support this premise, experiencing strong uplift in the Sentinel-1 analysis; however, it does support the proposition of mine water ponds moving homogenously, with the extents of motion defined by the pond. One potential contributory factor could be the accuracy of the divisions between ponds. For example, pond " 4 ", which extends from Newcastle to Durham, is considered to be sub-divided into further blocks. There are three major pumping stations within this block, the relationships between these pumping stations are complex and not well understood. Surface motion in the Sentinel-1 data supports the premise that pond " 4 " might be further divided into moving blocks. The results show InSAR can provide new information to help determine these boundaries.

For further scrutiny, comparisons are made in the following section between groundwater levels and ground motion at specific monitoring sites. 


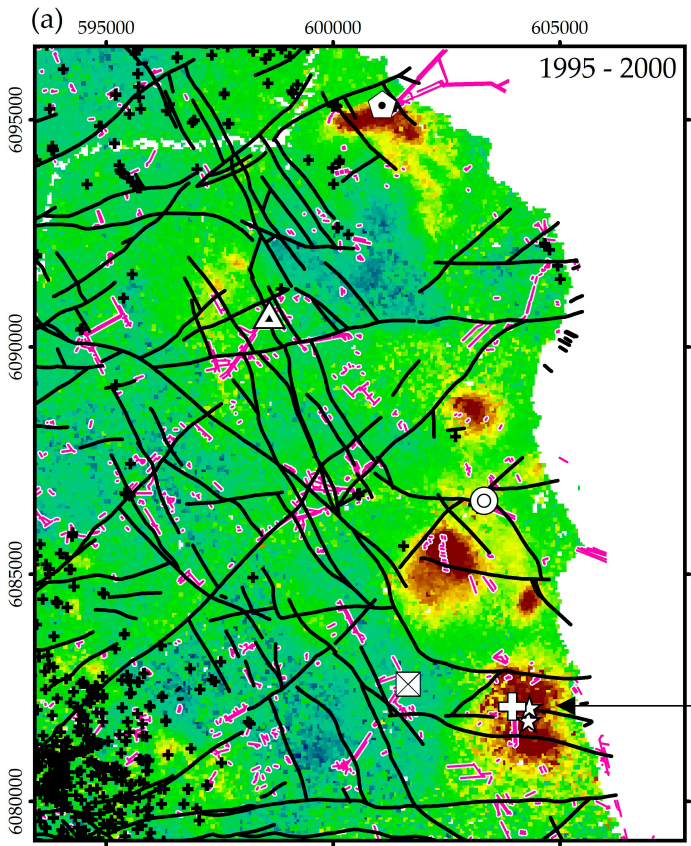

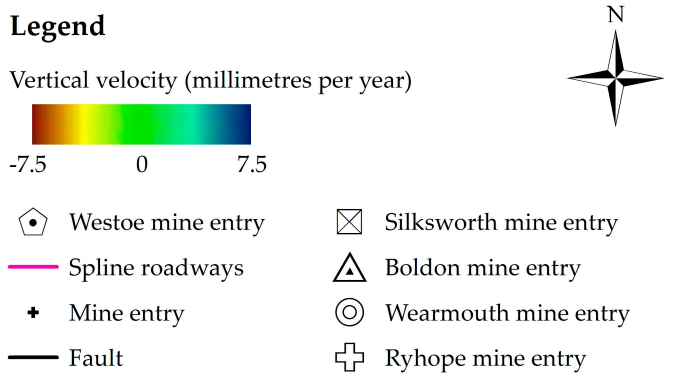
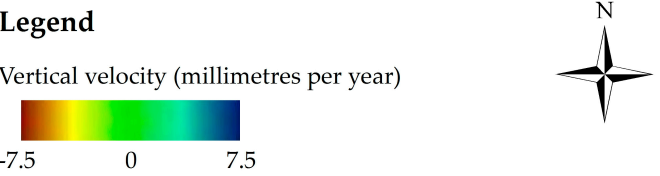

is Ryhope time-series (Figure 11)

Area of subsidence displaced from position of faults as indicated on the ERS deformation map
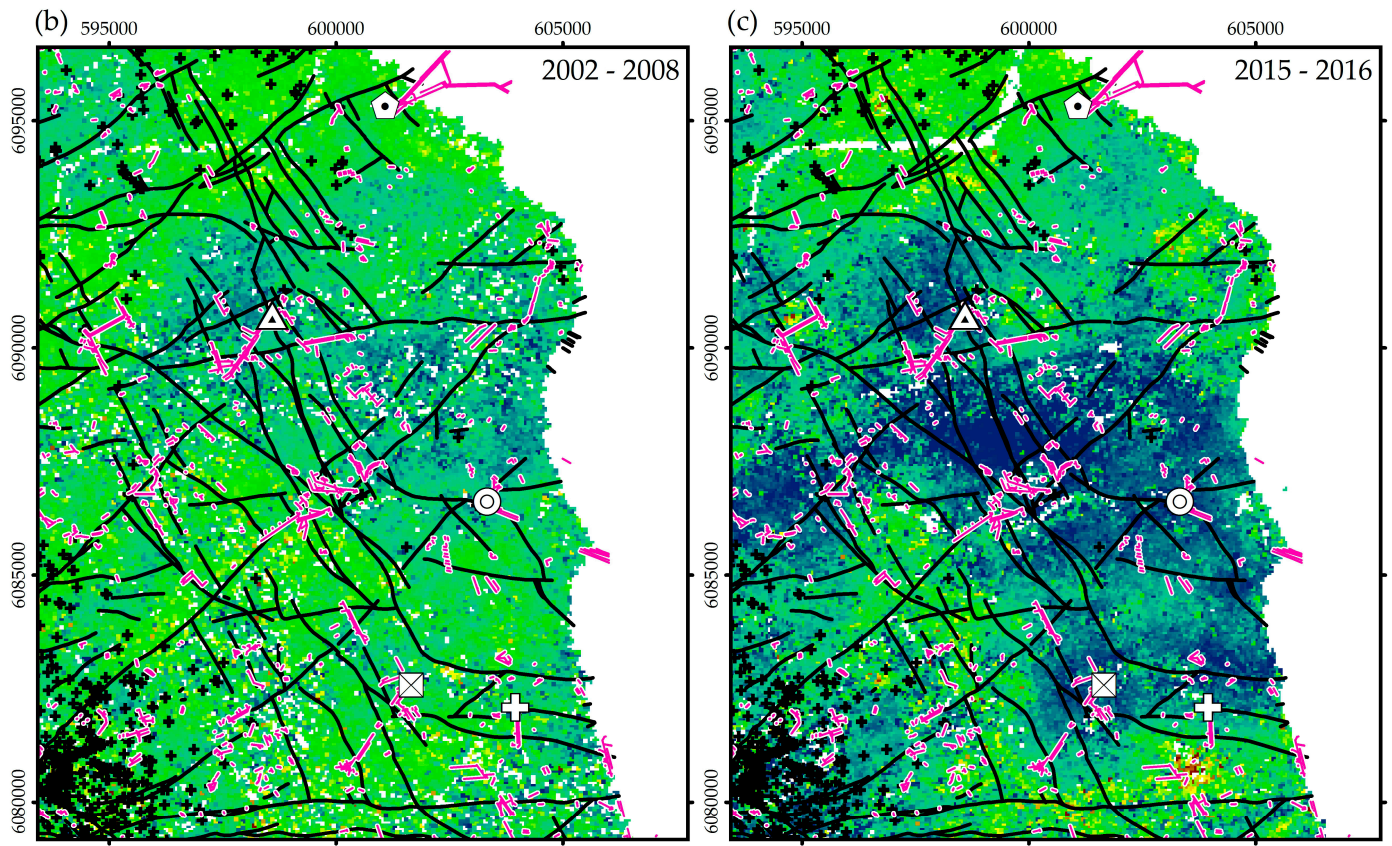

Figure 8. ISBAS vertical velocities (millimetres per year) in the surround area of Sunderland with faults, mine entries and spline roadways overlaid: (a) ERS (b) ENVISAT (c) Sentinel-1.

\subsection{Case Studies}

\subsubsection{Sunderland}

It was not until 1788, as exploration methods reached greater depths, that serious prospecting began in the Durham coastal limestone. Wearmouth colliery struck coal in 1834 at $480 \mathrm{~m}$ below sea level, making it the deepest coal mine in the world at the time. The Wearmouth Coal Company subsequently undermined most of the Sunderland area and in 1912 were calculating how much they could extract from underneath churches, hospitals, schools and St George's square before subsidence claims offset profits. In 1958, Wearmouth was identified as a 'super pit' from which 500 million tonnes of coal were extracted from under the North Sea, until the colliery was closed in 1993 [71]. Other 
smaller mines, just outside Sunderland, were later founded such as Ryhope (1859-1966), Boldon (1869-1982), Silksworth (1873-1971) and Westoe (1909-1993) [40].

The ERS analysis indicates a complex environment, identifying hotspots of deformation as well as areas of uplift (Figure 8). The most prominent subsidence identified in the ERS analysis spatially correlates to the collieries at Westoe, Wearmouth and Ryhope. Westoe and Wearmouth collieries shut in 1993, shortly before the period of ERS imagery (1995-2000), while, curiously, Ryhope closed in 1966, nearly four decades before the ERS analysis. The later ENVISAT data indicates a reversal in the velocities, with uplift present in some areas where subsidence was previously identified. By 2015-2016, the Sentinel-1 data reveal that uplift has both strengthened and spread out over a greater area.

Neighbouring time-series and linear velocities from ENVISAT and Sentinel-1 data correlate with rising groundwater monitored at Westoe, Wearmouth and Boldon, as shown in Figures 9 and 10. The ENVISAT time series are the noisiest due to the reduced amount of data acquisitions. There is a lack of correlation at Westoe and Wearmouth during the ERS time period where localised subsidence is identified; no groundwater data is available at Ryhope. From data provided by the Coal Authority and Harrison et al. (1989) [72] it is known that groundwater levels were rising sharply, through former workings, at Westoe and Wearmouth in the 1990s (Figures 9 and 10). Levels rose approximately $240 \mathrm{~m}$ at Westoe during this decade and approximately $315 \mathrm{~m}$ at Wearmouth between 1989 and 2002. It would be expected that if there is a collapse, for example caused by pillar failure, that strong localised subsidence will dominate the deformation signal over any moderate uplift caused by a rise in groundwater.
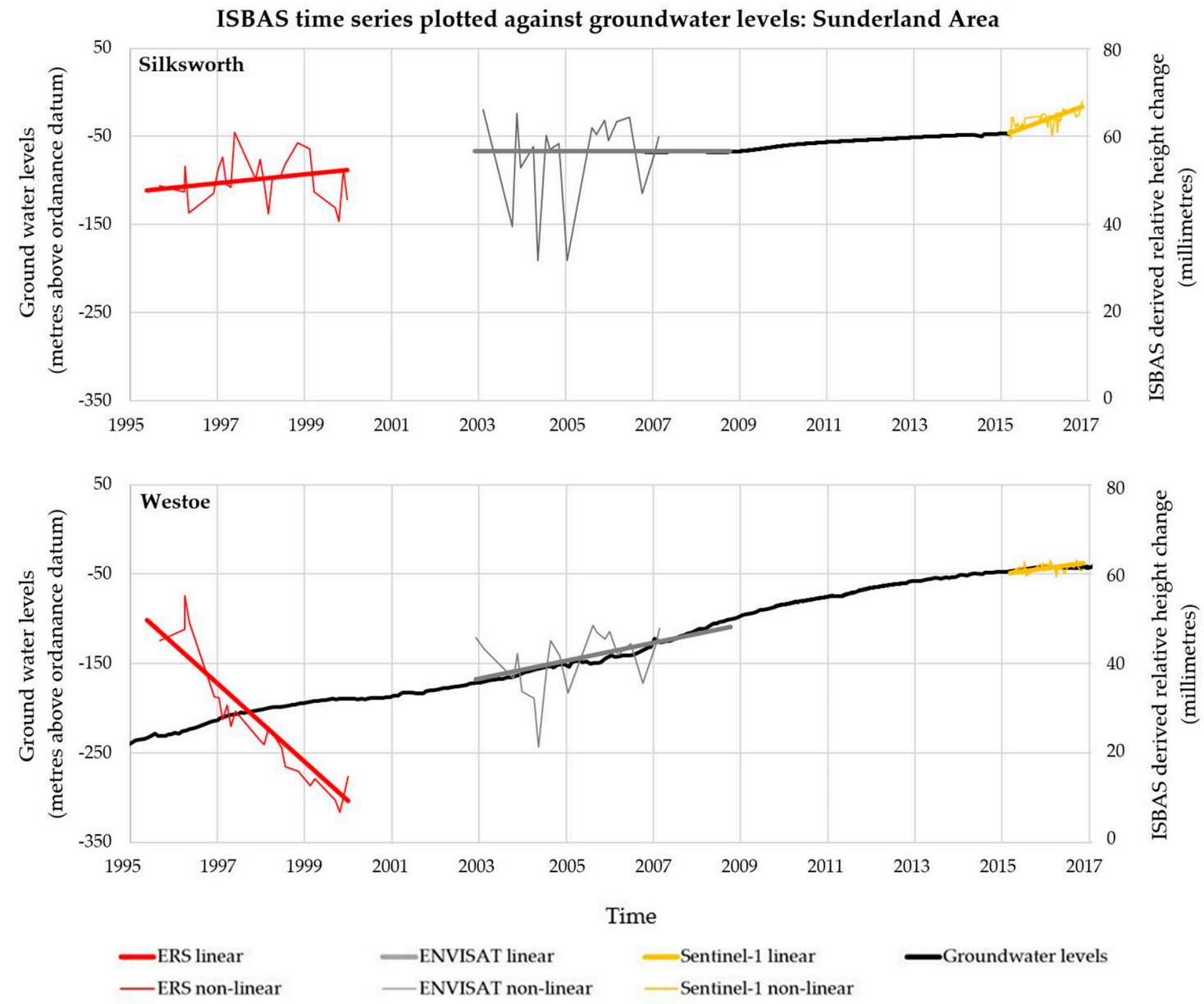

Figure 9. Groundwater levels plotted against neighbouring ISBAS time-series and linear velocities (derived separately) at Silksworth and Westoe, the locations of which are marked on Figure 8. 

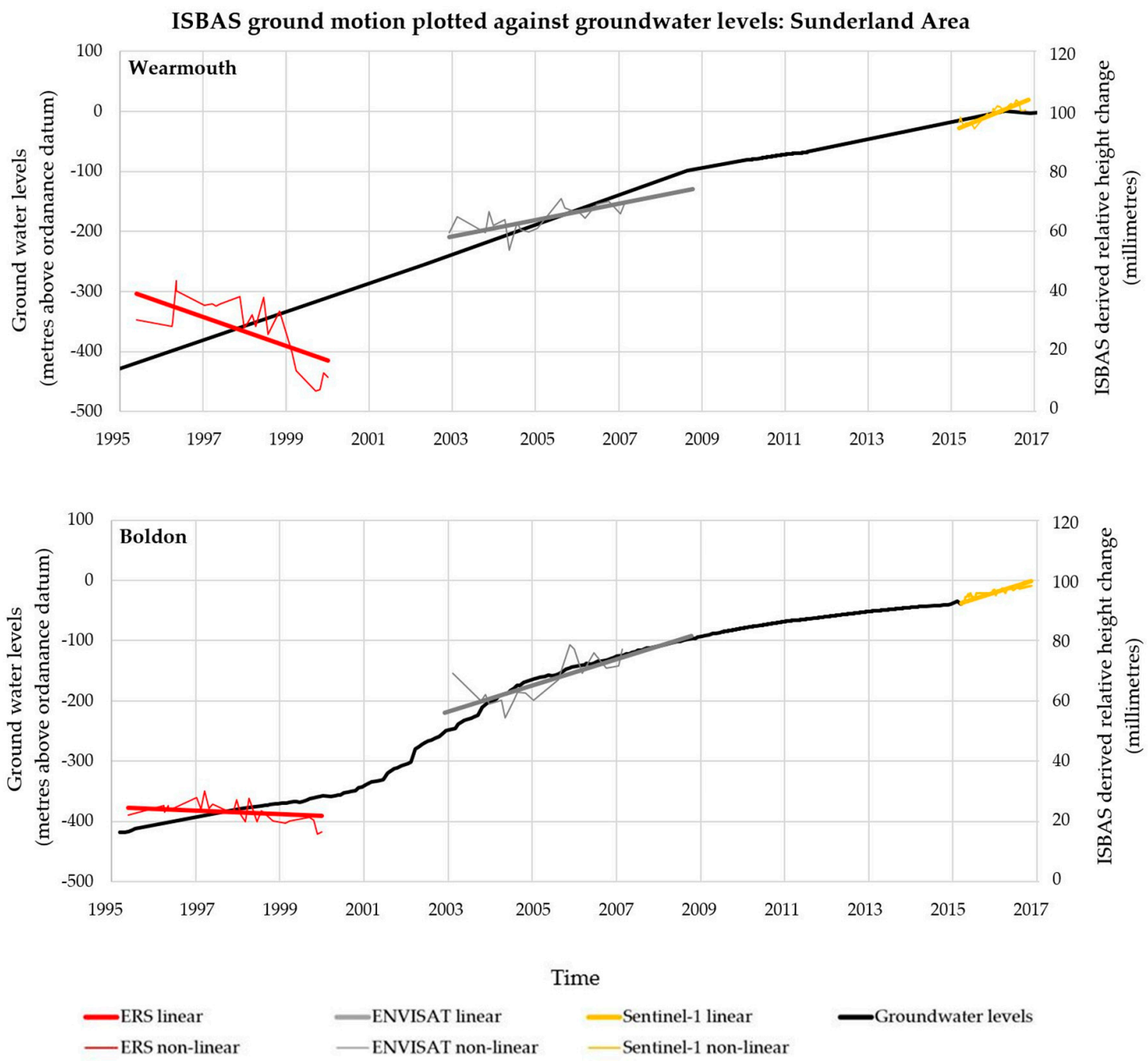

Figure 10. Groundwater levels plotted against neighbouring ISBAS time-series and linear velocities (derived separately) at Wearmouth and Boldon, the locations of which are marked on Figure 8.

Between 1998 and 1999, 20 earth tremors in the Ryhope area were reported over a 12 month period, with local residents from 14 different streets reporting vibrations [19]. Following an inconclusive investigation into the cause, four possible rationale were put forward: neotectonic processes; collapse of sub-surface cavities in the Magnesian limestone that overlie the Coal Measures; residual mining subsidence or rising mine water; the displacement of mine gases along the fault zone [73]. ERS time-series at Ryhope indicate an acceleration in the subsidence from July 1998, shortly before the period when the tremors were felt as shown in Figure 11.

A geological justification for the apparent offset of subsidence to faults thought to be controlling the motion is given in Figure 8. Subsidence at Ryhope, for example, appears bound by two east-west trending faults, albeit displaced slightly to the south with respect to the faults. The apparent offset of the subsidence to the bounding faults is likely due to the dip of the faults, with the assumed southward dipping fault planes intersecting the rockhead (or ground surface) at a more northerly point than that at which it confines the coal seam being mined at depth. 


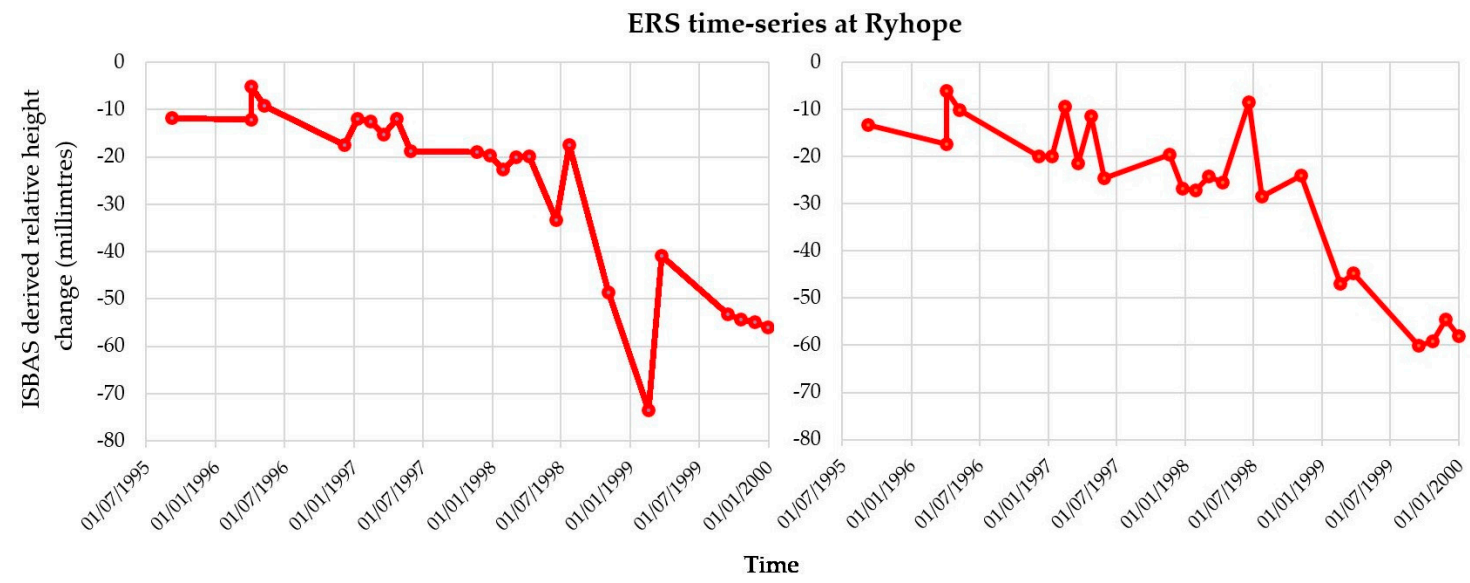

Figure 11. Selected ERS ISBAS time-series in the Ryhope subsidence depression, marked on Figure 8.

\subsubsection{Ashington}

The Ashington area has been extensively mined since the Bothal mining shaft was sunk in 1867, situated just over $3 \mathrm{~km}$ to the west of the Ashington shafts. Collieries quickly developed in the Ashington area remaining active until the rapid decline of the UK coal industry in the 1970s and 1980s, including: Ashington (1867-1986); Ellington (1905-2005); Woodhorn (1894-1981); Bates (1932-1986) and Bedlington (1838-1971) [40].

The land surface around Ashington is highly dynamic, where patterns of motion change significantly over the sequence of satellite acquisitions (Figure 12). During the ERS period of observations a localised hotspot of deformation spatially correlates with Ashington colliery, where seven mine entry shafts are connected to areas of underground workings via spline roadways. Groundwater levels at Ashington rose $30 \mathrm{~m}$ through former workings during this period of collapse. Further south, a large area of uplift is present, bound to the north by the ENE to WSW Stakeford fault, where differential motion is present over the fault. The southern tip of this area of uplift also appears delimited by faults. Subsidence occurring over Ashington has reduced during the ENVISAT period of observations, appearing less spatially correlated and distinct. To the south uplift is still present but the size and velocity has reduced. The Sentinel- 1 analysis indicates the region to the north of the Stakeford fault, is homogenously uplifting. Similarly to the temporal evolution of motion occurring around Sunderland, uplift in the Sentinel-1 analysis occurs over a broader area than previously identified subsidence. Motion is constrained by faults, most notably to the south by the Stakeford fault, and uplift correlates strongly with mined Coal Measures. South of the Stakeford fault, uplift has ceased, with the ground surface reaching approximate equilibrium.

Neighbouring time-series and linear velocities were compared against groundwater levels at former collieries to the south of the Stakeford fault, at Bates and Bedlington, and to the north, at Ellington and Woodhorn (Figure 13). These areas belong to separate mining blocks which the Stakeford fault delimits; there are no known connections through this boundary. At Bates and Bedlington, rising groundwater during the 1990s correlates with upward surface motion, a relationship which continues as groundwater levels return to the level of the ordnance datum in the early 2000s and the surface reaches equilibrium.

Subsidence had previously been identified at Bedlington, which occurred between 1990 and 1994 and produced a subsidence trough with a maximum settlement of $260 \mathrm{~mm}$ at the centre [74]. This resulted in the demolishing of Cloverdale terrace due to subsidence damage. Borehole investigations took place in 1994 and 1997; less than half of those drilled that were expected to encounter coal did. The boreholes identified much evidence of roof collapse and suggested that the pillars had deteriorated badly with time or had been reworked on retreat. It is thought areal subsidence was caused by small scale pillar failure, here, and at a similar nearby case study [75]. Mining at Bedlington ceased in 1971, 
long before the identified motion. From the groundwater levels provided by the Coal Authority and those published in Harrison et al. (1989) [72] it is known that groundwater levels rose approximately $150 \mathrm{~m}$ during the course of the 1990s; uplift is present during the ERS analysis in the latter half of the 1990s (Figure 12a).
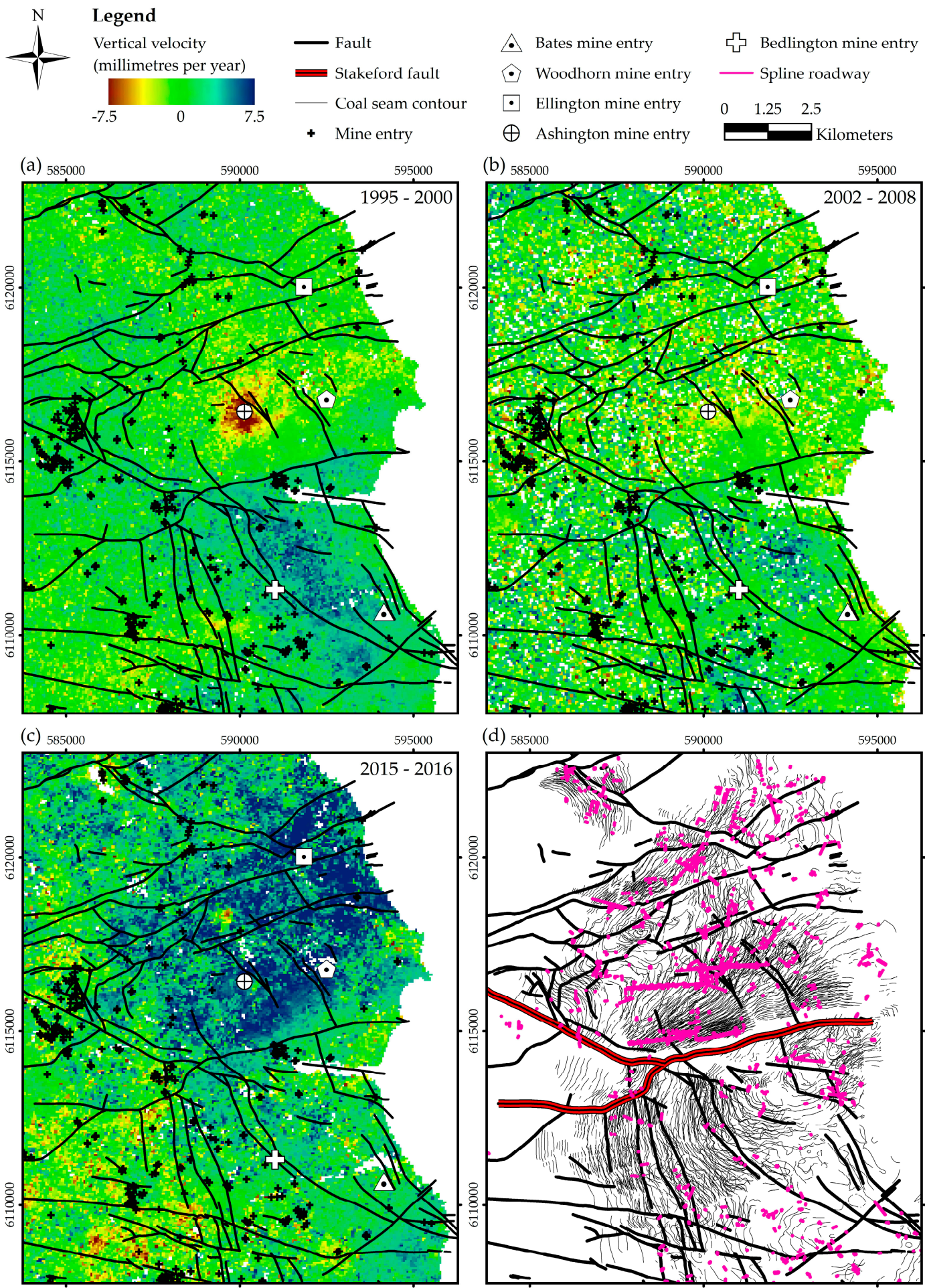

Figure 12. ISBAS vertical velocities (millimetres per year) in the surrounding area of Ashington with faults and mine entries overlaid: (a) ERS; (b) ENVISAT; (c) Sentinel-1; (d) Coal seam contours, faults and spline roadways. 

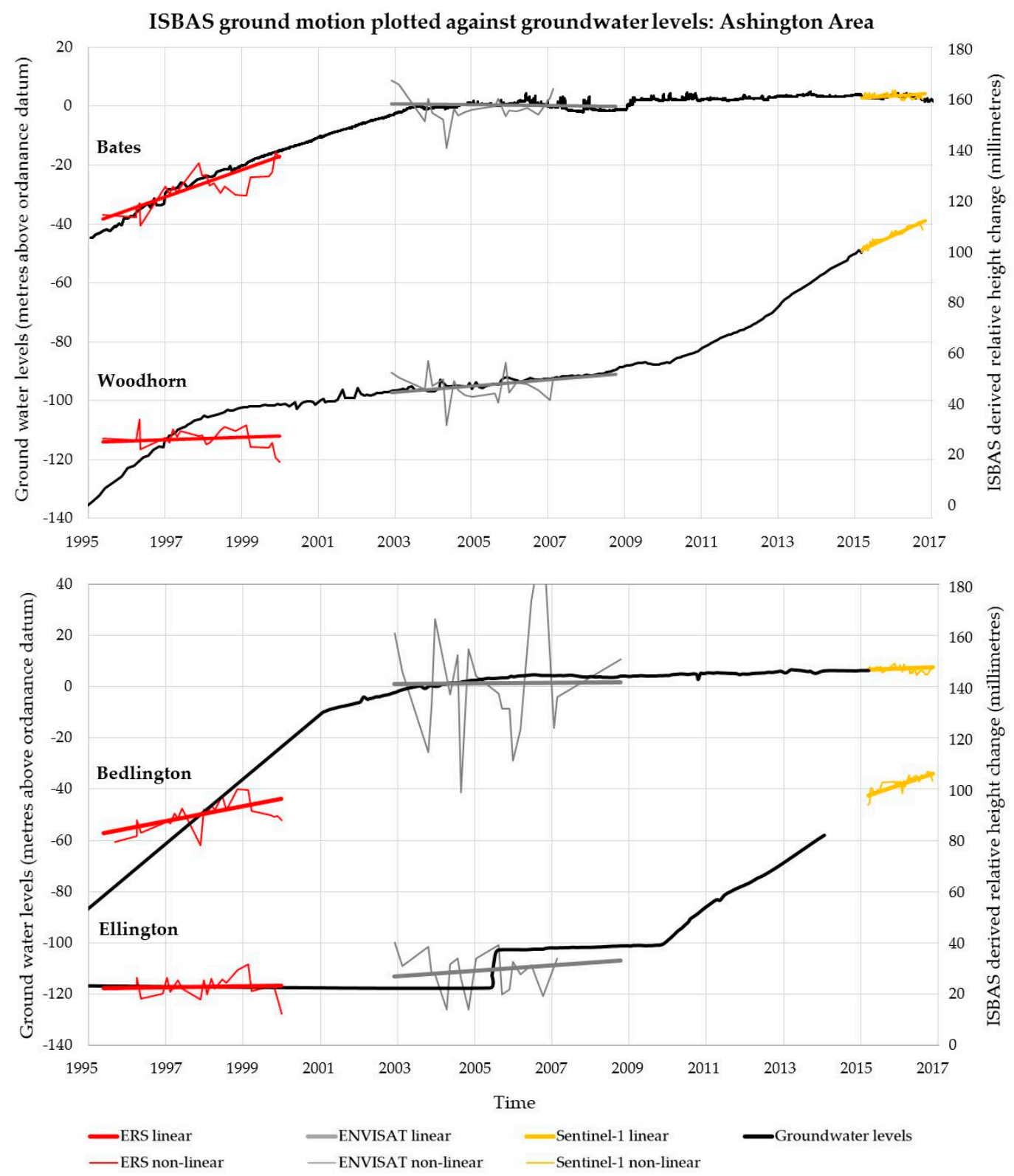

Figure 13. Groundwater levels plotted against neighbouring ISBAS time-series and linear velocities (derived separately) at Bates, Woodhorn, Bedlington and Ellington, the locations of which are marked on Figure 12.

At Ellington and Woodhorn the relationship between rising groundwater and surface velocities continues as strong uplift is identified in the Sentinel-1 data (Figure 13). The rate of groundwater recovery increases after approximately 2010, which is reflected in surface uplift in the Sentinel-1 analysis. Although groundwater data at these locations do not continue over the period of Sentinel-1 observations, on the assumption that levels continue to rebound as they have over the previous five years, a correlation between rising groundwater and the surface is present. Relative stability is identified at Ellington and Woodhorn during the ERS and ENVISAT observations.

Curiously, groundwater levels were rising at Woodhorn during the ERS time period, however the surface was relatively stable. It is, therefore, too simplistic to suggest surface uplift will occur in the surrounding locations where groundwater levels are rising. The volume of void space present in the coalfield could be one plausible explanation for the where there is no correlation. A rise in groundwater 
might only influence the surface when it is confined within the mine, i.e., once the void space in the mine has been filled, groundwater has reached the roof and is rising through the overburden. The depth to groundwater could also be a consideration; for example, it might be expected that a rise of $10 \mathrm{~m}$ in groundwater has less of an impact on the surface at a depth of $-400 \mathrm{~m}$ AOD, than it will at $-30 \mathrm{~m}$ AOD. Further research might also consider the potential effects aquifer groundwater levels could have on surface motion.

It should be noted that making a direct correlation between groundwater levels and deformation time-series here is challenging; at the majority of the sites investigated in this study groundwater measurements do not cover the epoch of InSAR acquisitions with sufficient frequency, particularly for ERS and Sentinel-1. For example, at Bedlington there is over a ten year gap (1989 and 2001) between groundwater measurements and only three out of eight sites investigated cover the entire Sentinel-1 period. At Bates, there is sufficient data to cover the all three InSAR acquisition periods; surface deformation is plotted against groundwater levels for the ERS time period (1995-2000) in Figure 14. Here, the coefficient of determination demonstrates that $\approx 65 \%$ of surface deformation is predicted by a rise in groundwater and that under these geological conditions a rise of $10 \mathrm{~m}$ in groundwater induces surface uplift of $8 \mathrm{~mm}$.

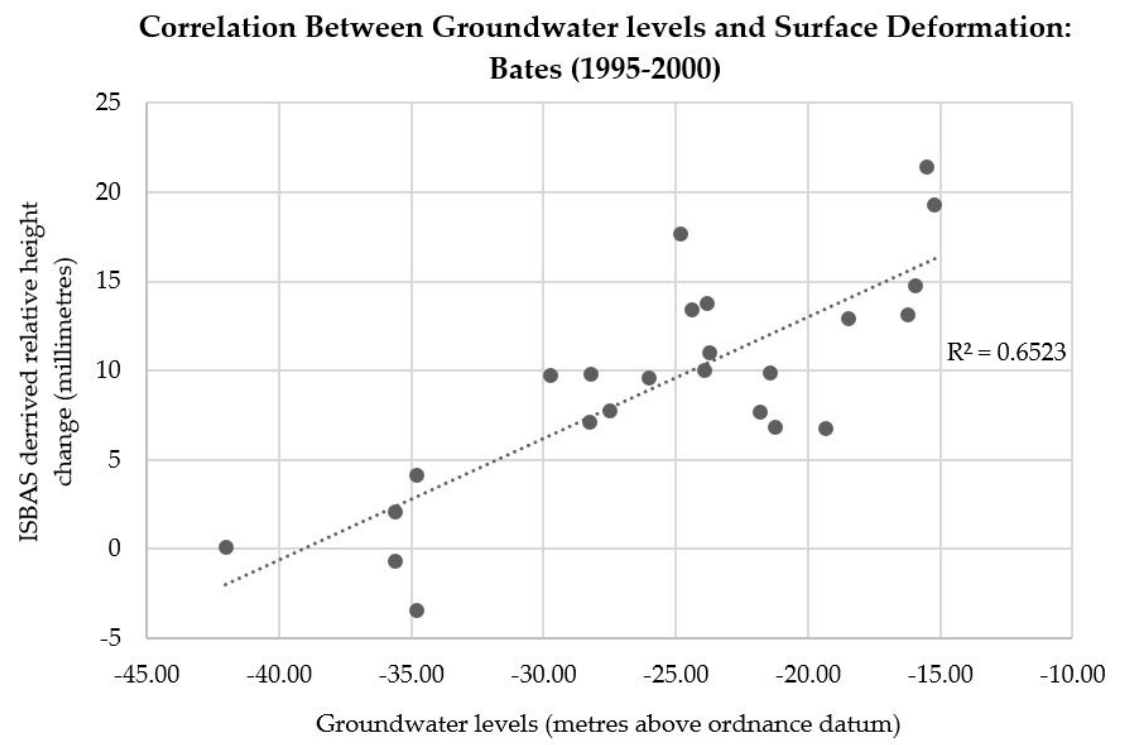

Figure 14. A linear regression between groundwater levels and surface deformation at Bates (Figure 12) for the ERS time period.

\section{Conclusions}

This study was undertaken to better delineate ground motion in the Northumberland and Durham coalfield over a 20-year time period. The ISBAS algorithm employed provides ground motion measurements that are consistent with those previously obtained using persistent scatterers interferometry on ERS and ENVISAT data, although the ISBAS approach provides a more complete spatial coverage of measurements.

The results show that unexpected amounts of ground motion are present in areas of former mining, occurring long after coal extraction has ceased. Localized subsidence has been identified over former mines during the late 1990s, with subsidence hotspots identified in proximity to former collieries. Regional patterns of uplift are present in all three data sets occurring over a larger spatial extent than any previously observed subsidence, often correlating with mined Coal Measures. An association was ascertained in proximity to former collieries that rising groundwater can be significant in influencing surface motion. The degree of influence rising mine water has on the surface requires further scrutiny in different geographies. 
This is important for the post-mining environment, and demonstrates that InSAR can provide a cost-effective regional outlook for making informed decisions to mitigate detrimental environmental effects in abandoned coalfields. The data shows how multifaceted post-closure ground deformation regimes can be with a complex interaction between the local stress field, regional groundwater recovery and accommodation and delimiting of motion by faults.

Acknowledgments: The work conducted here has been funded by the GeoEnergy Research Centre (GERC) and Geomatic Ventures Limited. The authors would like to acknowledge ESA for the provision of ERS, ENVISAT and Sentinel-1 SAR data; the Coal Authority for mining and hydrogeological data; the British Geological Survey for geological data and Chris Satterley for his role in the co-ordination of the study. Alessandro Novellino, Luke Bateson and Francesca Cigna publish with the permission of the Executive Director of BGS.

Author Contributions: David Gee, Andrew Sowter, Alessandro Novellino, Luke Bateson, Stephen Grebby Stuart Marsh and Chris Satterley conceived and designed the experiments; David Gee performed the experiments; all the authors analysed the data; David Gee, Luke Bateson and Stephen Grebby wrote the paper.

Conflicts of Interest: The authors declare no conflict of interest.

\section{Appendix A}

ERS SAR image dates and perpendicular baselines $B_{\perp}(m)$ in reference to the master image on 20 November 1997.

\begin{tabular}{cccc}
\hline Image Date & $\mathbf{B}_{\perp}(\mathbf{m})$ & Image Date & $\mathbf{B}_{\perp}(\mathbf{m})$ \\
\hline 20 November 1997 & 0 & 29 January 1998 & -431 \\
24 May 1995 & -610 & 5 March 1998 & -943 \\
7 September 1995 & -1361 & 9 April 1998 & -674 \\
3 April 1996 & -634 & 18 June 1998 & 302 \\
4 April 1996 & -689 & 23 July 1998 & -852 \\
8 May 1996 & 133 & 5 November 1998 & 449 \\
9 May 1996 & 58 & 18 February 1999 & 606 \\
9 January 1997 & -483 & 25 March 1999 & -790 \\
13 February 1997 & -821 & 16 September 1999 & -727 \\
20 March 1997 & -470 & 21 October 1999 & -639 \\
24 April 1997 & -870 & 25 November 1999 & -240 \\
29 May 1997 & -649 & 30 December 1999 & -172 \\
25 December 1997 & -499 & & \\
\hline
\end{tabular}

\section{Appendix B}

ENVISAT ASAR image dates and perpendicular baselines $B_{\perp}(m)$ in reference to the master image on 11 January 2005.

\begin{tabular}{cccc}
\hline Image Date & $\mathbf{B}_{\perp}(\mathbf{m})$ & Image Date & $\mathbf{B}_{\perp}(\mathbf{m})$ \\
\hline 11 January 2005 & 0 & 9 August 2005 & 627 \\
3 December 2002 & 1050 & 13 September 2005 & 437 \\
11 February 2003 & 500 & 22 November 2005 & 991 \\
14 October 2003 & 1336 & 27 December 2005 & 1023 \\
18 November 2003 & -179 & 7 March 2006 & 850 \\
23 December 2003 & 762 & 20 June 2006 & 744 \\
6 April 2004 & 1446 & 3 October 2006 & -33 \\
11 May 2004 & 179 & 16 January 2007 & 1284 \\
20 July 2004 & 857 & 20 February 2007 & 741 \\
24 August 2004 & 759 & 7 October 2008 & 629 \\
2 November 2004 & 794 & & \\
\hline
\end{tabular}




\section{Appendix C}

Sentinel-1 IW SAR image dates and perpendicular baselines $B_{\perp}(\mathrm{m})$ at scene centre in reference to the master image on 25 January 2006.

\begin{tabular}{cccc}
\hline Image Date & $\mathbf{B}_{\perp}(\mathbf{m})$ & Image Date & $\mathbf{B}_{\perp}(\mathbf{m})$ \\
\hline 25 January 2016 & 0 & 13 January 2016 & -58 \\
7 March 2015 & -101 & 6 February 2016 & -6 \\
19 March 2015 & -35 & 18 February 2016 & -73 \\
31 March 2015 & -41 & 1 March 2016 & -182 \\
12 April 2015 & -81 & 13 March 2016 & -153 \\
24 April 2015 & -103 & 25 March 2016 & -97 \\
6 May 2015 & -62 & 6 April 2016 & -40 \\
18 May 2015 & -55 & 18 April 2016 & -96 \\
30 May 2015 & -127 & 30 April 2016 & -136 \\
11 June 2015 & -138 & 12 May 2016 & -193 \\
23 June 2015 & -178 & 5 June 2016 & -43 \\
5 July 2015 & -104 & 29 June 2016 & -143 \\
17 July 2015 & -27 & 11 July 2016 & -152 \\
14 November 2015 & -62 & 23 July 2016 & -69 \\
26 November 2015 & 37 & 16 August 2016 & -74 \\
8 December 2015 & -21 & 9 September 2016 & -158 \\
20 December 2015 & -77 & 21 September 2016 & -166 \\
1 January 2016 & -139 & 15 October 2016 & -6 \\
\hline
\end{tabular}

\section{References}

1. Rosen, P.A.; Hensley, S.; Joughin, I.R.; Li, F.K.; Madsen, S.N.; Rodriguez, E.; Goldstein, R.M. Synthetic aperture radar interferometry. Proc. IEEE 2000, 88, 333-382. [CrossRef]

2. Massonnet, D.; Feigl, K.L. Radar interferometry and its application to changes in the Earth's surface. Rev. Geophys. 1998, 36, 441-500. [CrossRef]

3. Hooper, A.; Bekaert, D.; Spaans, K.; Arıkan, M. Recent advances in SAR interferometry time series analysis for measuring crustal deformation. Tectonophysics 2012, 514, 1-3. [CrossRef]

4. Colesanti, C.; Mouelic, S.L.; Bennani, M.; Raucoules, D.; Carnec, C.; Ferretti, A. Detection of mining related ground instabilities using the Permanent Scatterers technique-A case study in the east of France. Int. J. Remote Sens. 2005, 26, 201-207. [CrossRef]

5. Herrera, G.; Tomás, R.; López-Sánchez, J.M.; Delgado, J.; Mallorqui, J.J.; Duque, S.; Mulas, J. Advanced DInSAR analysis on mining areas: La Union case study (Murcia, SE Spain). Eng. Geol. 2007, 90, 148-159. [CrossRef]

6. Du, Z.; Ge, L.; Li, X.; Ng, A.H. Subsidence monitoring over the Southern Coalfield, Australia using both L-Band and C-Band SAR time series analysis. Remote Sens. 2016, 8, 543. [CrossRef]

7. Yang, Z.; Li, Z.; Zhu, J.; Yi, H.; Hu, J.; Feng, G. Deriving dynamic subsidence of coal mining areas using InSAR and logistic model. Remote Sens. 2017, 9, 125. [CrossRef]

8. Kratzsch, H. Mining Subsidence Engineering; Springer: Berlin/Heidelberg, Germany, 1983.

9. Peng, S.S.; Ma, W.; Zhong, W. Surface Subsidence Engineering; Society for Mining, Metallurgy, and Exploration: Littleton, CO, USA, 1992.

10. Sowter, A.; Bateson, L.; Strange, P.; Ambrose, K.; Syafiudin, M.F. DInSAR estimation of land motion using intermittent coherence with application to the South Derbyshire and Leicestershire coalfields. Remote Sens. Lett. 2013, 4, 979-987. [CrossRef]

11. Zebker, H.A.; Villasenor, J. Decorrelation in interferometric radar echoes. IEEE Trans. Geosci. Remote Sens. 1992, 30, 950-959. [CrossRef]

12. Ferretti, A.; Colesanti, C.; Perissin, D.; Prati, C.; Rocca, F. Evaluating the effect of the observation time on the distribution of SAR permanent scatterers. In Proceedings of the FRINGE 2003 Workshop, Frascati, Italy, 1-5 December 2003; pp. 1-5. 
13. Cigna, F.; Sowter, A. The relationship between intermittent coherence and precision of ISBAS InSAR ground motion velocities: ERS-1/2 case studies in the UK. Remote Sens. Environ. 2017. [CrossRef]

14. Berardino, P.; Fornaro, G.; Lanari, R.; Sansosti, E. A new algorithm for surface deformation monitoring based on small baseline differential SAR interferograms. IEEE Trans. Geosci. Remote Sens. 2002, 40, 2375-2383. [CrossRef]

15. Sowter, A.; Amat, M.B.; Cigna, F.; Marsh, S.; Athab, A.; Alshammari, L. Mexico City land subsidence in 2014-2015 with Sentinel-1 IW TOPS: Results using the Intermittent SBAS (ISBAS) technique. Int. J. Appl. Earth Obs. Geoinf. 2016, 52, 230-242. [CrossRef]

16. Gee, D.; Sowter, A.; Novellino, A.; Marsh, S.; Gluyas, J. Monitoring land motion due to natural gas extraction: Validation of the Intermittent SBAS (ISBAS) DInSAR algorithm over gas fields of North Holland, the Netherlands. Mar. Pet. Geol. 2016, 77, 1338-1354. [CrossRef]

17. Novellino, A.; Athab, A.D.; bin Che Amat, M.A.; Syafiudin, M.F.; Sowter, A.; Marsh, S.; Cigna, F.; Bateson, L. Intermittent SBAS Ground Motion Analysis in Low Seismicity Areas: Case Studies in the Lancashire and Staffordshire Coalfields, UK, Seismology from SPACE: Geodetic Observations and Early Warning of Earthquakes; Royal Astronomical Society, Burlington House: London, UK, 2014.

18. Bateson, L.; Cigna, F.; Boon, D.; Sowter, A. The application of the Intermittent SBAS (ISBAS) InSAR method to the South Wales Coalfield, UK. Int. J. Appl. Earth Obs. Geoinf. 2015, 34, 249-257. [CrossRef]

19. Donnelly, L.J. A review of coal mining induced fault reactivation in Great Britain. Q. J. Eng. Geol. Hydrogeol. 2006, 39, 5-50. [CrossRef]

20. Culshaw, M.G.; Tragheim, D.; Bateson, L.; Donnelly, L.J. Measurement of ground movements in Stoke-on-Trent (UK) using radar interferometry. In Proceedings of the 10th Congress of the International Association for Engineering Geology and the Environment, IAEG2006, Nottingham, UK, 6-10 September 2006; Geological Society: London, UK, 2006; pp. 1-10.

21. Banton, C.; Bateson, L.; Mccormack, H.; Holley, R.; Watson, I.; Burren, R.; Lawrence, D.; Cigna, F. Monitoring post-closure large scale surface deformation in mining areas. In Proceedings of the Mine Closure 2013, Eighth International Conference on Mine Closure 2013, Australian Centre for Geomechanics, Perth Eden Project, Cornwall, UK, 18-20 September 2013.

22. Bateson, L.; Lawrence, D. Terrafirma Product: Interpretation Report. V1. 1: Northumberland. Available online: http:/ / nora.nerc.ac.uk/21035/1/OR12054.pdf (accessed on 8 September 2017).

23. Copernicus Land Monitoring Service. Available online: http://land.copernicus.eu/pan-european/corineland-cover/clc-2012/view (accessed on 15 May 2017).

24. Clarke, S.M. The Geology of NY76NW (S), Cawfields, Northumberland; British Geological Survey Open Report, OR/07/034; British Geological Survey: Nottingham, UK, 2007; p. 28.

25. Stone, P.; Millward, D.; Young, B.; Merritt, J.W.; Clarke, S.M.; McCormac, M.; Lawrence, D.J.D. British Regional Geology: Northern England, 5th ed.; British Geological Survey: Nottingham, UK, 2010.

26. Lawley, R; Garcia-Bajo, M. The National Superficial Deposit Thickness Model (Version 5); British Geological Survey Internal Report, OR/09/049; British Geological Survey: Nottingham, UK, 2009; p. 18.

27. Smailes, A.E. The development of the Northumberland and Durham coalfield. Scott. Geogr. Mag. 1935, 51, 201-214. [CrossRef]

28. Clarke, B.G.; Welford, M.; Hughes, D.B. The threat of abandoned mines on the stability of urban areas. In Proceedings of the 10th Congress of the International Association for Engineering Geology and the Environment, IAEG2006, Nottingham, UK, 6-10 September 2006; Geological Society: London, UK, 2006.

29. European Space Agency: SAR Image Mode. Available online: https:/ / earth.esa.int/web/guest/missions / esa-operational-eo-missions/ers/instruments/sar/design (accessed on 15 May 2017).

30. Cigna, F.; Rawlins, B.G.; Jordan, C.J.; Sowter, A.; Evans, C. Intermittent Small Baseline Subset (ISBAS) InSAR of rural and vegetated terrain: A new method to monitor land motion applied to peatlands in Wales, UK. In Proceedings of the EGU General Assembly, Vienna, Austria, 27 April-2 May 2014.

31. Farr, T.G.; Rosen, P.A.; Caro, E.; Crippen, R.; Duren, R.; Hensley, S.; Kobrick, M.; Paller, M.; Rodriguez, E.; Roth, L.; et al. The shuttle radar topography mission. Rev. Geophys. 2007, 45. [CrossRef]

32. Chen, C.W.; Zebker, H.A. Two-dimensional phase unwrapping with use of statistical models for cost functions in nonlinear optimization. J. Opt. Soc. Am. A Opt. Image Sci. Vis. 2001, 18, 338-351. [CrossRef] [PubMed] 
33. European Space Agency: Interferometric Wide Swath. Available online: https://sentinel.esa.int/ web/sentinel/user-guides/sentinel-1-sar/acquisition-modes/interferometric-wide-swath (accessed on 15 May 2017).

34. Novellino, A.; Cigna, F.; Brahmi, M.; Sowter, A.; Bateson, L.; Marsh, S. Assessing the feasibility of a national InSAR ground deformation map of Great Britain with Sentinel-1. Geosciences 2017, 7, 19. [CrossRef]

35. Davidson, G.; Mantle, V.; Rabus, B.; Williams, D.; Geudtner, D. Implementation of TOPS mode on RADARSAT-2 in support of the Sentinel-1 mission. In Proceedings of the Living Planet Symposium, Edinburgh, UK, 9-13 Septmber 2013; pp. 1-22.

36. Jolivet, R.; Grandin, R.; Lasserre, C.; Doin, M.P.; Peltzer, G. Systematic InSAR tropospheric phase delay corrections from global meteorological reanalysis data. Geophys. Res. Lett. 2011, 38. [CrossRef]

37. González, P.J.; Fernandez, J. Error estimation in multitemporal InSAR deformation time series, with application to Lanzarote, Canary Islands. J. Geophys. Res. Solid Earth 2011, 116. [CrossRef]

38. Mills, D.A.; Holliday, D.W. Geology of the District around Newcastle upon Tyne, Gateshead and Consett: Memoir for 1:50,000 Geological Sheet 20 (England and Wales); British Geological Survey: Nottingham, UK, 1998; p. 20.

39. Norton, P.J. Mine closure and associated hydrological effects on the environment: Some case studies. In Minerals, Metals and the Environment II. Institute of Mining and Metallurgy; Elsevier Applied Science: London, UK, 1996; pp. 263-270.

40. Durham Mining Museum: Collieries. Available online: http://www.dmm.org.uk/colliery/ (accessed on 15 May 2017).

41. Bell, F.G.; Genske, D.D. The influence of subsidence attributable to coal mining on the environment, development and restoration; some examples from Western Europe and South Africa. Environ. Eng. Geosci. 2001, 7, 81-99. [CrossRef]

42. Pôttgens, J.J. Uplift as a result of rising mine waters (in German). The Development Science and Art of Minerals Surveying. In Proceedings of the 6th International Congress of the International Society for Mine Surveying, Harrogate, UK, 9-13 September 1985; Volume 2, pp. 928-938.

43. Donnelly, L.J. A review of international cases of fault reactivation during mining subsidence and fluid abstraction. Q. J. Eng. Geol. Hydrogeol. 2009, 42, 73-94. [CrossRef]

44. Bekendam, R.F.; Pottgens, J.J. Ground movements over the coal mines of southern Limburg, The Netherlands, and their relation to rising mine waters. IAHS Publ.-Ser. Proc. Rep.-Int. Assoc. Hydrol. Sci. 1995, 234, 3-12.

45. Chen, C.T.; Hu, J.C.; Lu, C.Y.; Lee, J.C.; Chan, Y.C. Thirty-year land elevation change from subsidence to uplift following the termination of groundwater pumping and its geological implications in the Metropolitan Taipei Basin, Northern Taiwan. Eng. Geol. 2007, 95, 30-47. [CrossRef]

46. Devleeschouwer, X.; Declercq, P.Y.; Flamion, B.; Brixko, J.; Timmermans, A.; Vanneste, J. Uplift revealed by radar interferometry around Liège (Belgium): A relation with rising mining groundwater. In Proceedings of the Post-Mining Symposium, Nancy, France, 6-8 February 2008; pp. 6-8.

47. Cuenca, M.C.; Hooper, A.J.; Hanssen, R.F. Surface deformation induced by water influx in the abandoned coal mines in Limburg, The Netherlands observed by satellite radar interferometry. J. Appl. Geophy. 2013, 88, 1-11. [CrossRef]

48. Samsonov, S.; d'Oreye, N.; Smets, B. Ground deformation associated with post-mining activity at the French-German border revealed by novel InSAR time series method. Int. J. Appl. Earth Obs. Geoinf. 2013, 23, 142-154. [CrossRef]

49. Graniczny, M.; Colombo, D.; Kowalski, Z.; Przyłucka, M.; Zdanowski, A. New results on ground deformation in the Upper Silesian Coal Basin (southern Poland) obtained during the DORIS Project (EU-FP 7). Pure Appl. Geophys. 2015, 172, 3029-3042. [CrossRef]

50. Przyłucka, M.; Herrera, G.; Graniczny, M.; Colombo, D.; Béjar-Pizarro, M. Combination of conventional and advanced DInSAR to monitor very fast mining subsidence with TerraSAR-X Data: Bytom City (Poland). Remote Sens. 2015, 7, 5300-5328. [CrossRef]

51. Vervoort, A.; Declercq, P.Y. Surface movement above old coal longwalls after mine closure. Int. J. Min. Sci. Technol. 2017, in press. [CrossRef]

52. Younger, P.L. Coalfield closure and the water environment in Europe. Min. Technol. 2002, 111, $201-209$. [CrossRef] 
53. Wojtkowiak, F.; Couillet, J.C.; Daupley, X.; Tauziede, C. Geotechnical and environmental impacts on the surface of the water rising in French underground coal mines after closure. In Proceedings of the 7th International Mine Water Association Symposium (IMWA 2000), Ustron, Poland, 11-15 September 2000; pp. 180-194.

54. Smith, F.W.; Underwood, B. Mine closure: The environmental challenge. Min. Technol. 2000, 109, $202-209$. [CrossRef]

55. Donnelly, L. Investigation of Geological Hazards \& Mining Risks, Gallowgate, Newcastle-upon-Tyne. In Proceedings of the 10th IAEG International Congress, (IAEG 2006), Nottingham, UK, 6-10 September 2006.

56. Poulsen, B.A.; Shen, B.; Williams, D.J.; Huddlestone-Holmes, C.; Erarslan, N.; Qin, J. Strength reduction on saturation of coal and coal measures rocks with implications for coal pillar strength. Int. J. Rock Mech. Min. Sci. 2014, 71, 41-52. [CrossRef]

57. Knott, D.L. Assessment of potential subsidence impacts from coal mining using test borings, mine maps and empirical methods. In Proceedings of the 2006 Interstate Technical Group on Abandoned Underground Mines Meeting, Rochester, NY, USA, 14-16 June 2006; pp. 1-40.

58. Castellanza, R.; Gerolymatou, E.; Nova, R. An attempt to predict the failure time of abandoned mine pillars. Rock Mech. Rock Eng. 2008, 41, 377. [CrossRef]

59. Smith, J.; Colls, J.J. Groundwater rebound in the Leicestershire Coalfield. Water Environ. J. 1996, 10, $280-289$. [CrossRef]

60. Raleigh, C.B.; Healy, J.H.; Bredehoeft, J.D. An experiment in earthquake control at Rangely, Colorado. Science 1976, 191, 1230-1237. [CrossRef] [PubMed]

61. Ingebritsen, S.E.; Sanford, W.E. Groundwater in Geologic Processes; Cambridge University Press: Cambridge, UK, 1999.

62. Donnelly, L.J. Reactivation of geological faults during mining subsidence from 1859 to 2000 and beyond. Min. Technol. 2000, 109, 179-190. [CrossRef]

63. Younger, P.L. Hydrogeochemistry of minewaters flowing from abandoned coal workings in County Durham. Q. J. Eng. Geol. Hydrogeol. 1995, 28 (Suppl. 2), S101-S113. [CrossRef]

64. Yu, M.H.; Jefferson, I.F.; Culshaw, M.G. Fault reactivation, an example of environmental impacts of groundwater rising on urban area due to previous mining activities. In Proceedings of the 11th Congress of the International Society for Rock Mechanics, Lisbon, Portugal, 9-13 July 2007.

65. Environment Agency. Personal Communication; Environment Agency: Bristol, UK, 2012.

66. Sherwood, J.M.; Younger, P.L. Modelling groundwater rebound after coalfield closure: An example from County Durham, UK. In Proceedings of the 5th International Mine Water Congress, University of Nottingham and IMWA, Nottingham, UK, 18-23 September 1994; pp. 767-777.

67. Younger, P.L.; Adams, R. Predicting Mine Water Rebound: Research E Development Technical Report W179; Environment Agency: Bristol, UK, 1999. [CrossRef]

68. Adams, R.; Younger, P.L. A strategy for modeling ground water rebound in abandoned deep mine systems. Ground Water 2001, 39, 249-261. [CrossRef] [PubMed]

69. Kortas, L.; Younger, P.L. Using the GRAM model to reconstruct the important factors in historic groundwater rebound in part of the Durham Coalfield, UK. Mine Water Environ. 2007, 26, 60-69. [CrossRef]

70. Adams, R. A Review of mine water rebound predictions from the VSS-NET model. Mine Water Environ. 2014, 33, 384-388. [CrossRef]

71. Victoria County History: Coal-Mining. Available online: https://www.victoriacountyhistory.ac.uk/sites / default/files/work-in-progress/coal-mining.pdf (accessed on 15 May 2017).

72. Harrison, R.; Scott, W.B.; Smith, T. A note on the distribution, levels and temperatures of minewaters in the Northumberland and Durham coalfield. Q. J. Eng. Geol. Hydrogeol. 1989, 22, 355-358. [CrossRef]

73. IMC Consulting Engineers Ltd. Report on Earth Tremors at Ryhope; The Coal Authority: Mansfield, UK, 1999.

74. Sizer, K.E.; Gill, M. Pillar failure in shallow coal mines-A recent case history. Min. Technol. 2000, 109, 146-152. [CrossRef]

75. Coal Authority. Personal Communication; Coal Authority: Mansfield, UK, 2017.

(C) 2017 by the authors. Licensee MDPI, Basel, Switzerland. This article is an open access article distributed under the terms and conditions of the Creative Commons Attribution (CC BY) license (http:/ / creativecommons.org/licenses/by/4.0/). 